\title{
ORCHID ITINERARIES OF AUGUSTUS R. ENDRÉS IN CENTRAL AMERICA: A BIOGRAPHIC AND GEOGRAPHIC SKETCH
}

\author{
Carlos Ossenbach ${ }^{1,2}$, Franco Pupulin $^{1,3,4} \&$ Rudolf Jenny ${ }^{5}$ \\ ${ }^{1}$ Centro de Investigación en Orquídeas de los Andes "Ángel Andreetta”, \\ Universidad Alfredo Pérez Guerrero, Ecuador \\ ${ }^{2}$ Orquideario 25 de Mayo, San José, Costa Rica \\ ${ }^{3}$ Lankester Botanical Garden, University of Costa Rica \\ ${ }^{4}$ Harvard University Herbaria, Cambridge, MA, U.S.A. \\ ${ }^{5}$ Jany Renz Herbarium, Swiss Orchid Foundation
}

\begin{abstract}
A.R. Endrés, as he was known until recent research revealed most of his relevant biographical data, was the most important orchid collector to visit Costa Rica. Besides collecting the type specimens for some one hundred new orchid species, he discovered, described and illustrated thousands of orchid plants, most of which remained still undescribed during his life time. One of the outstanding aspects of the collections made by Endrés in just a few years in the post-colonial Costa Rica of the Nineteenth century is his impressive knowledge of the country, in terms of geographical coverage, which in several cases extended beyond the limits of the already explored territories. The present paper presents for the first time the most important biographical facts about Endrés' life and his orchidologic work in Central America. The main exploratory routes made by Endrés are highlighted in the framework of the social geography of his time, and a complete catalogue of the localities where he made his orchid collections, referenced to modern geographical coordinates, is presented.
\end{abstract}

Resumen. A.R. Endrés, como fue conocido hasta que investigaciones recientes revelaron gran parte de sus datos biográficos relevantes, fue el más importante colector de orquídeas que jamás visitó Costa Rica. Además de recolectar los especímenes tipo de casi un centenar de nuevas especies de orquídeas, Endrés descubrió, describió e ilustró miles de plantas de orquídeas, muchas de ellas aún sin describir a la época de sus hallazgos. Uno de los rasgos sobresalientes de las colecciones llevadas a cabo por Endrés en la Costa Rica post-colonial del siglo diecinueve es su impresionante conocimiento del país, en términos de cobertura geográfica, que en muchos casos se extiende más allá de los límites de los territorios ya explorados en estos entonces. El presente trabajo presenta por vez primera los datos biográficos más importantes de Endrés y de su trabajo orquidológico en América Central. Se resaltan las rutas exploratorias más relevantes realizadas por Endrés, explicándolas en el marco de la geografía social de su época y se presenta un catálogo completo de las localidades en las que realizó sus colectas, referenciándolas con coordenadas geográficas modernas.

Key Words: Augustus R. Endrés, botanical history, orchidology, Costa Rica, geography

"There is a young man by the name of $A$. $R$. Endrés living in Costa Rica, who has devoted the past four or five years to investigating the Botany of the interior of that republic. He is still devoted to that purpose and has made many important discoveries of new plants.

I have no doubt that you might draw him into correspondence withyou, altho' his correspondence is chiefly with European botanists, and particularly with Reichenbach, the distinguished orchidologist of Germany, to whom Mr. Endrés sends the major portion of his collections for description and publication" (John M. Dow, 1873).

Introduction. The disclosure of Costa Rican orchid diversity during the second half of the Nineteenth century is profoundly indebted to the exploratory and botanical work by Augustus R. Endrés. Heinrich Gustav Reichenbach (1870, 1871, 1872a, 1872b, 1872ca, 1872d, 1872e, 1873, 1874a, 1874b, 1875a, $1875 \mathrm{~b}, 1875 \mathrm{c}, 1875 \mathrm{~d}, 1876,1877 \mathrm{a}, 1877 \mathrm{~b}, 1881$, 1883), George Nicholson (1886), Friedrich Richard 
Rudolf Schlechter (1921), Friedrich Wilhelm Ludwig Kränzlin (1920, 1921, 1922, 1923, 1925), Carlyle August Luer (1992, 1995, 1996, 1999), and Franco Pupulin (2001), described almost one hundred orchid species on the basis of plants collected by Endrés during his journey in Costa Rica. The type specimens collected by Endrés belong today to several orchid genera, such as Ada Lindl., Barbosella Schltr., Barkeria Knowles \& Westc., Benzingia Dodson, Chondroscaphe (Dressler) Senghas \& Gerlach, Cischweinfia Dressler \& N.H. Wiliams, Cryptarrhena R.Br., Dichaea Lindl., Epidendrum L., Huntleya Batem. ex Lindl., Kefersteinia Rchb.f., Lepanthes Sw., Lockhartia Hook., Lycaste Lindl., Masdevallia Ruiz \& Pav., Maxillaria Ruiz \& Pav., Maxillariella M.A. Blanco \& Carnevali, Miltoniopsis Godefr. \& Leb., Nitidobulbon I. Ojeda, Carnevali \& G.A. Romero, Oncidium Sw., Pleurothallis R.Br., Pleurothallopsis Porto \& Brade, Polycycnis Rchb.f., Restrepia Kunth, Scaphosepalum Pfitz., Scaphyglottis Poepp. \& Endl., Sievekingia Rchb.f., Sigmatostalix Rchb.b., Stanhopea Frost. ex Hook., Stelis Sw., Stenotyla Dressler, Telipogon Kunth, Trichocentrum Poepp. \& Endl., Trisetella Luer, and Zootrophion Luer.

The thousands of plants, sketches, analytical drawings, habitat notes and botanical descriptions prepared by Endrés from 1866 to 1874, when he mostly resided in Costa Rica and now at the Herbarium and the Archives of the Natural History Museum in Vienna (NHMW), form an extraordinary legacy, still today largely waiting for in-depth scrutiny and interpretation. Besides the relatively few taxa based on his Costa Rica gatherings, Endrés collected, illustrated and described literally hundreds of species that were still new to the science at the time of his findings. These materials are now fully accessible to the public through the web page of the NHMW (2010), where high-resolution digital images of Endrés' botanical legacy were made available thanks to a joint effort by the NHMW, the University of Costa Rica, and the Jany Renz Herbarium at the University of Basel.

Very little, however, was traditionally known about Endrés himself, with the exception of the preliminary attempts at biographical sketches offered by Luer (1995) and variously taken up again by Atwood and Mora-Retana (1992-1993), Ossenbach (2003, 2009), and Pupulin and Ossenbach (2005).
One of the outstanding aspects of the collections made by Endrés in just a few years in the post-colonial Costa Rica of the Nineteenth century is his impressive knowledge of the country, in terms of geographical coverage. Several of the localities indicated by Endrés in his notes, or affixed to the dry specimens and drawings he regularly sent to his main correspondent, Prof. Reichenbach at Hamburg, were at that time at the extreme bounds of the known territories of a still unexplored country. Some of them correspond today to prosperous villages and towns, but they are recorded by Endrés just as the farms and hamlets, mines, pastures, trails, or simple sites, as they were at the time he visited these localities for the first time. The present paper is a first attempt to produce a complete catalogue of the itineraries and the localities where Endrés made his orchid collections, explaining them in the framework of the social geography of Nineteenth Century Costa Rica, and giving them a modern geographical reference (Appendix 1).

The only exception, and one that can only be explained by sheer lack of time, is that there is not a single orchid specimen collected by Endrés in the mountain pass of La Palma, to the North and Northwest of San José, in the saddle between the Barva and Irazú volcanoes. Although easily accessible through the old trail to Carrillo, this area was not explored until the first decades of the Twentieth Century, when the Brade brothers, Wercklé, Tonduz, and many others discovered dozens of new species, mostly described by Rudolf Schlechter.

Augustus R. Endrés (1838-1874) . A few days after Christmas, in the last days of the year 1866, a young botanist of just 28 years of age landed at Greytown (=San Juan del Norte) on the Caribbean coast of Nicaragua (Endrés, 1867). Augustus R. Endrés, born in the small village of Herbitzheim in Alsace as the son of the local school teacher on November 27, 1838 (Herbitzheim, 2008) had preceded his family, who emigrated some years later to the United States, and arrived in New York sometime in the year of 1855 (Archives départementales du Bas-Rhin, 2010a, 2010b). Eleven years later, on December 13, 1866, Endrés was granted U.S. citizenship and received an American passport (United States National Archives and Records Administration, 2008, 2008b). On the same day, and with a freshly signed contract in his 


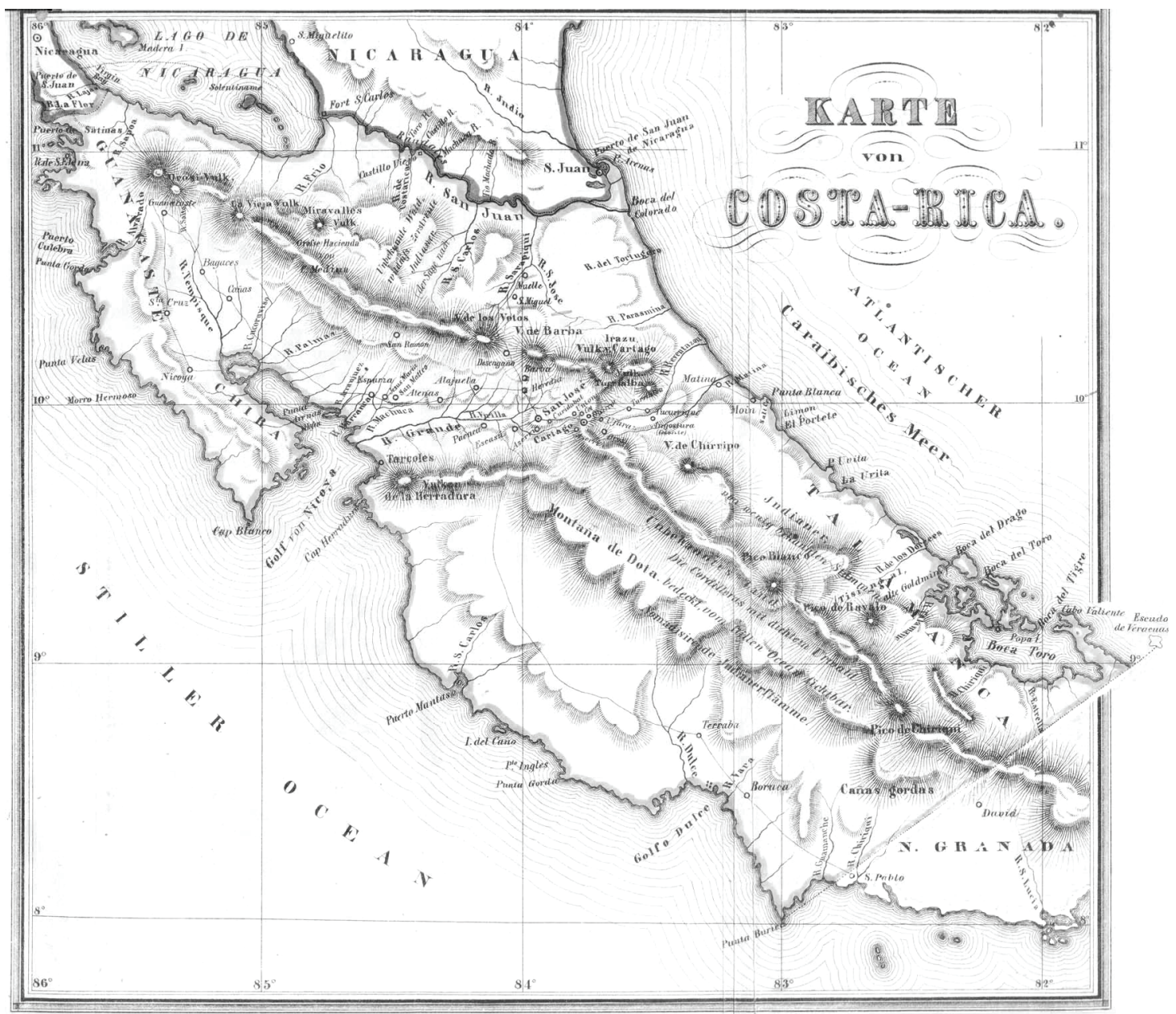

Figure 1. Map of Costa Rica by Wagner \& Scherzer. The most modern map of the country available at the time of Endrés' arrival. In Wagner \& Scherzer, 1856.

pocket to collect orchids for James Bateman of England and Heinrich Gustav Reichenbach, Director of the Hamburg Botanical Garden, he applied for a passport, with which he embarked on the next available ship to Central America (Endrés, 1871). However, although being born as a citizen of the French Empire and having obtained the United States nationality, Endrés remained, through the rest of his short life, faithful to his German extraction, culture and language.

Over the next seven and a half years Endrés would become a legendary figure in the botanical exploration of Costa Rica and undoubtedly the most important orchidologist who ever visited the Central American countries (Fig. 1-2). In 1871 he rescinded his contract with Bateman and Reichenbach and went into an agreement with the house of Veitch, which lasted until 1873 (Endrés, 1871; Veitch, 1906).

On January 12,1874 , shortly before leaving Costa Rica, Endrés wrote in San José his last known letter to Captain John M. Dow. Having failed in achieving the celebrity and prosperity he always dreamed of, his words were full of bitterness: "Reichenbach has lately repeated his proposal of buying my dried orch. collections and I fear our first interview will be a stormy one. I begin to consider these cabinet-celebrities as vampires nourishing their inflated fame at the cost of the lifeblood of those poor fools they condescendingly call "collectors", and I am thoroughly disgusted, at moments, with the pursuits I have so passionately followed for seven years" (Endrés, 1874). 


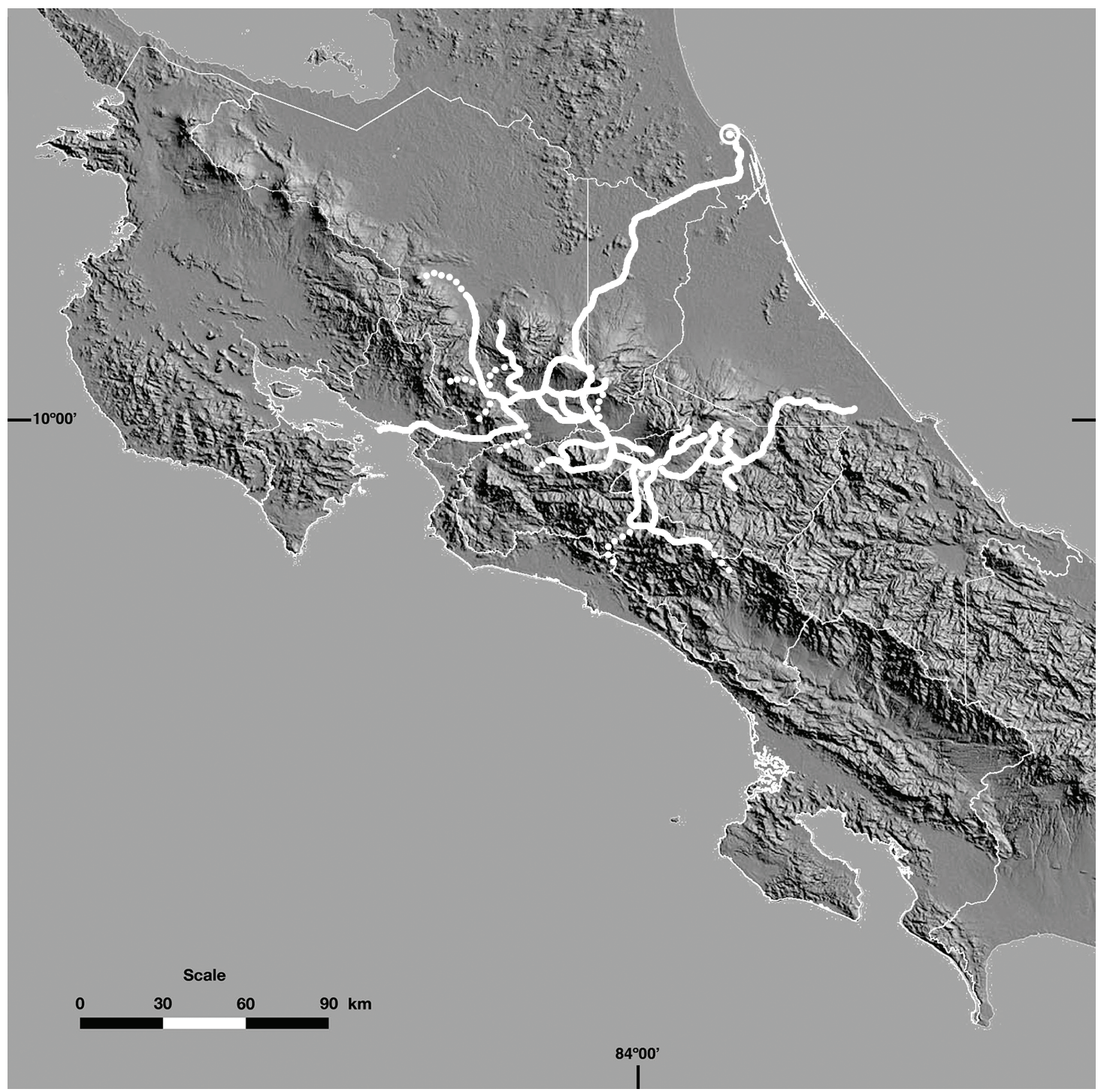

FIgURE 2. General map of the known itineraries by A.R. Endrés in Costa Rica.

In April of 1874 Endrés left Costa Rica on a journey from which he would never return. After traveling to Puntarenas and sailing from there to Panama, he embarked to Europe in April of 1874 (Endrés, 1874). During the early summer of 1874 he met with Reichenbach in Hamburg. Nothing is known about their conversation, except for a brief note by Reichenbach who in 1875 wrote that he had had " $a$ few delightful days, full of Orchid talk and chat, with Messrs. Roezl and Endres at Hamburg" (Reichenbach, 1875b).
On July 15 of that year he embarked again for America, this time in the company of the famous Czech plant collector Benedikt Roezl, landing on August 2 in New York (United States National Archives and Records Administration, 2008c). After a short excursion with Roezl to Niagara Falls, he sailed to Barranquilla, on the Caribbean coast of Colombia. During the last week of October he continued on what would be his last collecting excursion, this time eastwards to the Sierra Nevada of Santa Marta. After falling ill with pleurisy in the small village of San 


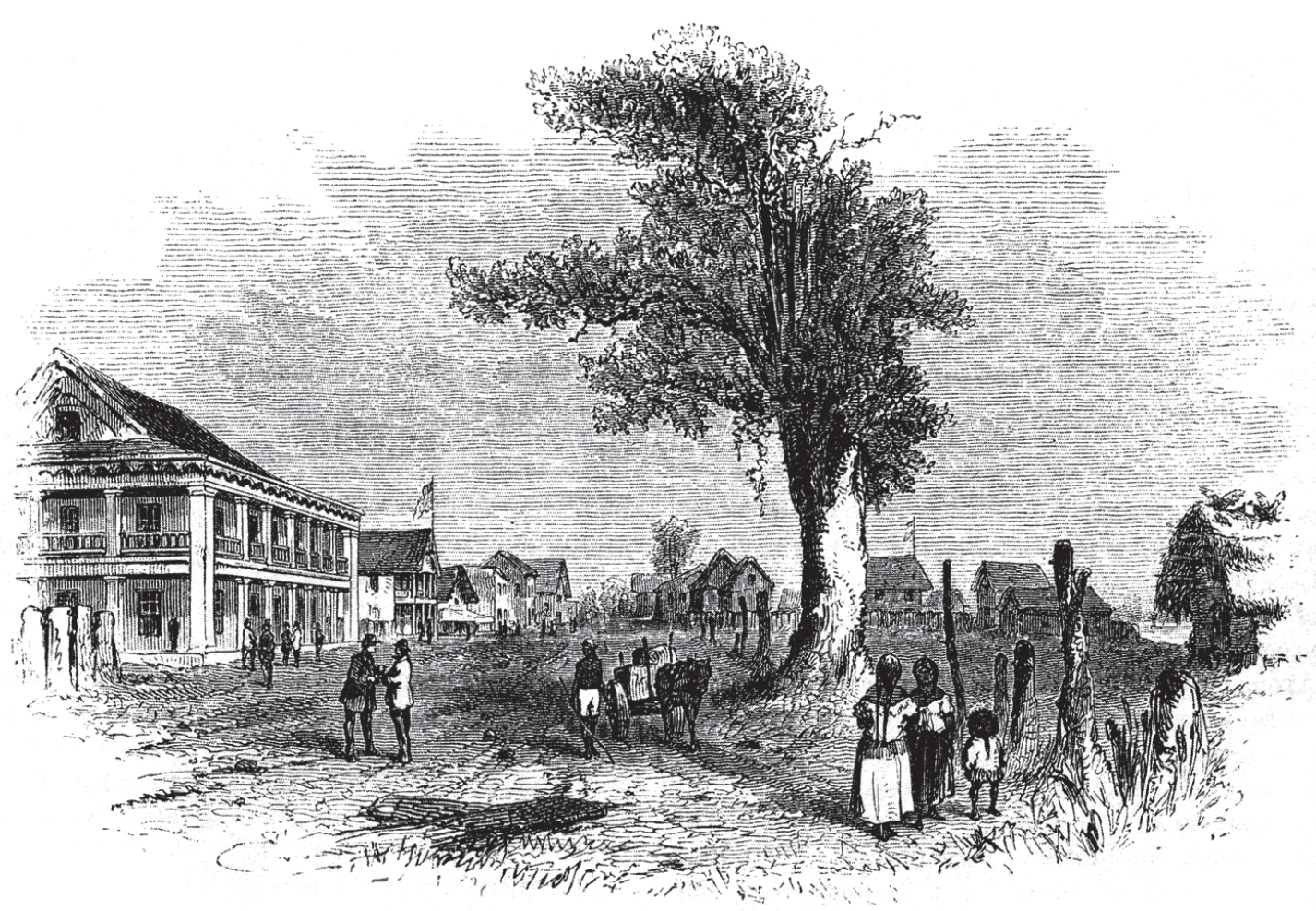

FIgURE 3. King Street in Greytown. In Vargas, 2008.

Antonio, at 3,000 feet altitude on the northeastern slope of the Sierra, he was brought by local Indians to the costal village of Dibulla, where, in the words of Franz Flux, officer of the German Consulate in Barranquilla, "he started on his journey to the afterworld at the end of November [of 1874]" (Flux, 1875).

\section{The orchid itineraries of Augustus R. Endrés in Costa Rica}

THe 'Far' Northeast and the ROAd of Sarapiquí. After arriving in Greytown, Endrés spent several months in the Atlantic region of Nicaragua and Costa Rica. According to undocumented reports, Endrés settled temporarily with English and German colonists along the San Carlos and Sarapiquí rivers (L.D. Gómez, pers. comm. 2008). There he worked at least part-time with a Mr. Koschny in beginning a plantation of native rubber and nutmeg (Gómez, L. D. in Luer, 1995).

The port of Greytown, and the rivers San Juan and Sarapiquí were part of the "road of Sarapiquí", at that time the only route connecting the highland valleys of Costa Rica and the Caribbean coast. Travelers embarked in Greytown (Fig.3) on primitive canoes and after navigating the treacherous sandbars on the mouth of the San Juan went up the river and continued into the Sarapiquí until they reached the village of El Muelle, the only available river landing on this stream. From there, on foot and on mules, travelers took the trail to the villages of La Virgen and San Miguel through virgin forests and climbed over the mountain pass of El Desengaño, descending from an altitude of almost 10,000 feet to Costa Rica's Central Valley and the country's capital, San José (Fig. 4). Only passable during the dry season, the road was equally important to travelers and for the import of goods into the country. Costa Rica's first piano and first printing press came into the country via Greytown and Sarapiquí.

The first notice of this route dates back to 1620 , when Diego de Mercado, at the request of the Spanish authorities, who were interested in finding a way between the Atlantic and the Pacific because 


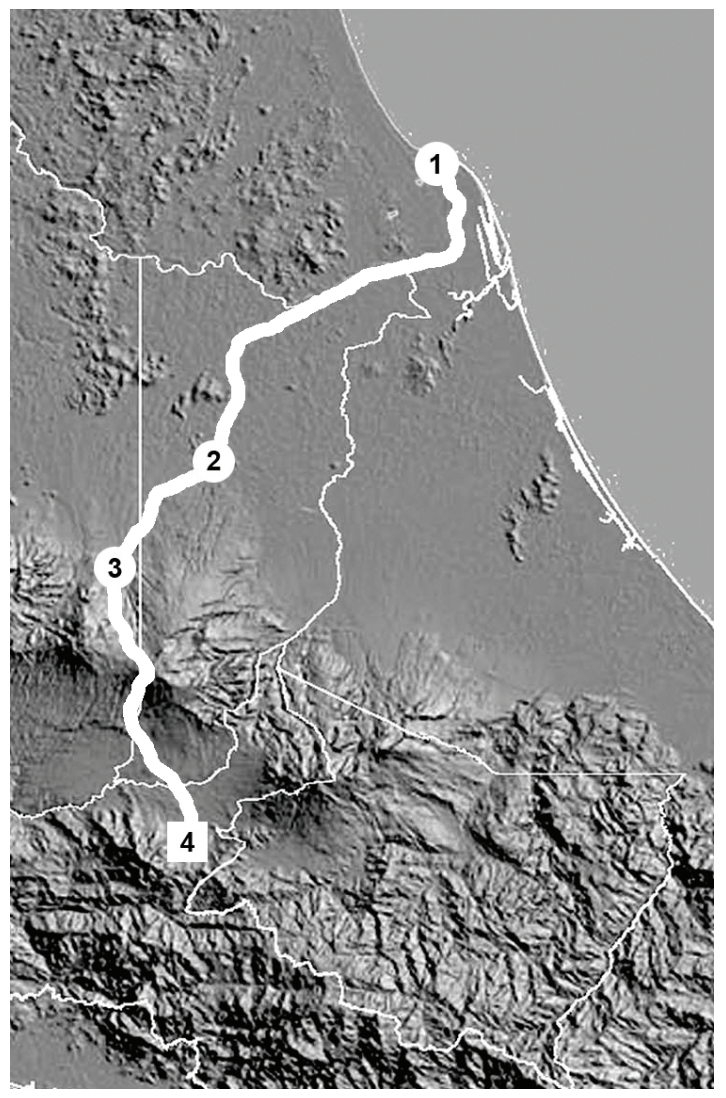

FIgURE 4. The 'far' Northeast and the road of Sarapiquí. 1

- San Juan (Greytown). 2 - Muelle. 3 - San Miguel. 4

- San José.

of the insalubrity of Panama, submitted a report to the government in Guatemala in which he stated that he had found the desired communication along two different routes. "The first one navigating upstream along the 'Desaguadero' [the Drainage, or the San Juan River] to the mouth of the Sarapiquí, then upstream for more than twenty leagues and from that point to the Royal Embarkment (the mouth of the Tempisque River on the Pacific coast). The road was of "hard earth and not marshy'..." The other route consisted in what was later known as the Nicaragua Canal, sailing the San Juan River upstream to the Lake of Nicaragua and building from there a canal to the Pacific Coast (Secretaría de Gobierno, 1924).

Shortly after Costa Rica's independence from Spain in 1821, Richard Trevithick (1771-1833), a British inventor and mining engineer, whose most significant success had been the high pressure steam engine and the first full-scale working railway steam locomotive, arrived in Costa Rica hoping to develop mining machinery. He spent time looking for a practical route to transport ore and equipment, settling on using the San Juan River, the Sarapiquí River, and then a railway to cover the remaining distance. Trevithick had in mind a steam-driven and not a mule-driven railway. After almost loosing his life along the route, Trevithick abandoned the idea in 1827, returned to England and never came back to Costa Rica (Gutiérez Braun, 1981). The road of Sarapiquí lost importance against the route from Costa Rica's Pacific port of Puntarenas to Panama and Colón once the railroad across the Isthmus of Panama was inaugurated in 1855.

A more easterly route to the road of Sarapiquí was built in 1880, which communicated San José with the Sucio River and joined there the new railroad to Port Limón. It was named the 'road of Carrillo', in remembrance of President Braulio Carrillo (18001845) who had first envisioned the need for better communications with the Atlantic region. Finally, the railroad between San José and Port Limón was completed in 1890. However, the road of Sarapiquí, expanded in the early 1900's for the circulation of motor vehicles, remained the most important access to Costa Rica's Atlantic region until the late 1960's, when the present roads to Port Limón (the first over Turrialba and Siquirres and the second other over the Zurquí tunnel) were inaugurated.

Endrés first known orchid collection in Costa Rica, a specimen of Dichaea trulla Rchb. f., carries the date "1866" (W Rchb-Orch 18037/W 0019163, Fig. 5 ) and was undoubtedly collected in the Caribbean watersheds of the Sarapiquí and San Juan rivers, where this species is still fairly common. There is no mention of other plant collections by Endrés along the "road of Sarapiquí", but we know that he arrived in San José on May 25, 1867, after following this route. In a letter of that date to Capt. John M. Dow, Endrés writes about having 'lately' received a letter from a Mr. Buchanan [of New York] in Greytown, indicating that he had been living in that region from December 1866 until at least March or April of 1867. In said letter to Dow he states that he "arrived here [in San José] this morning" (Endrés, 1867).

It is interesting that Endrés' first impression of Costa Rica was that "it [...] would be a useless waste 

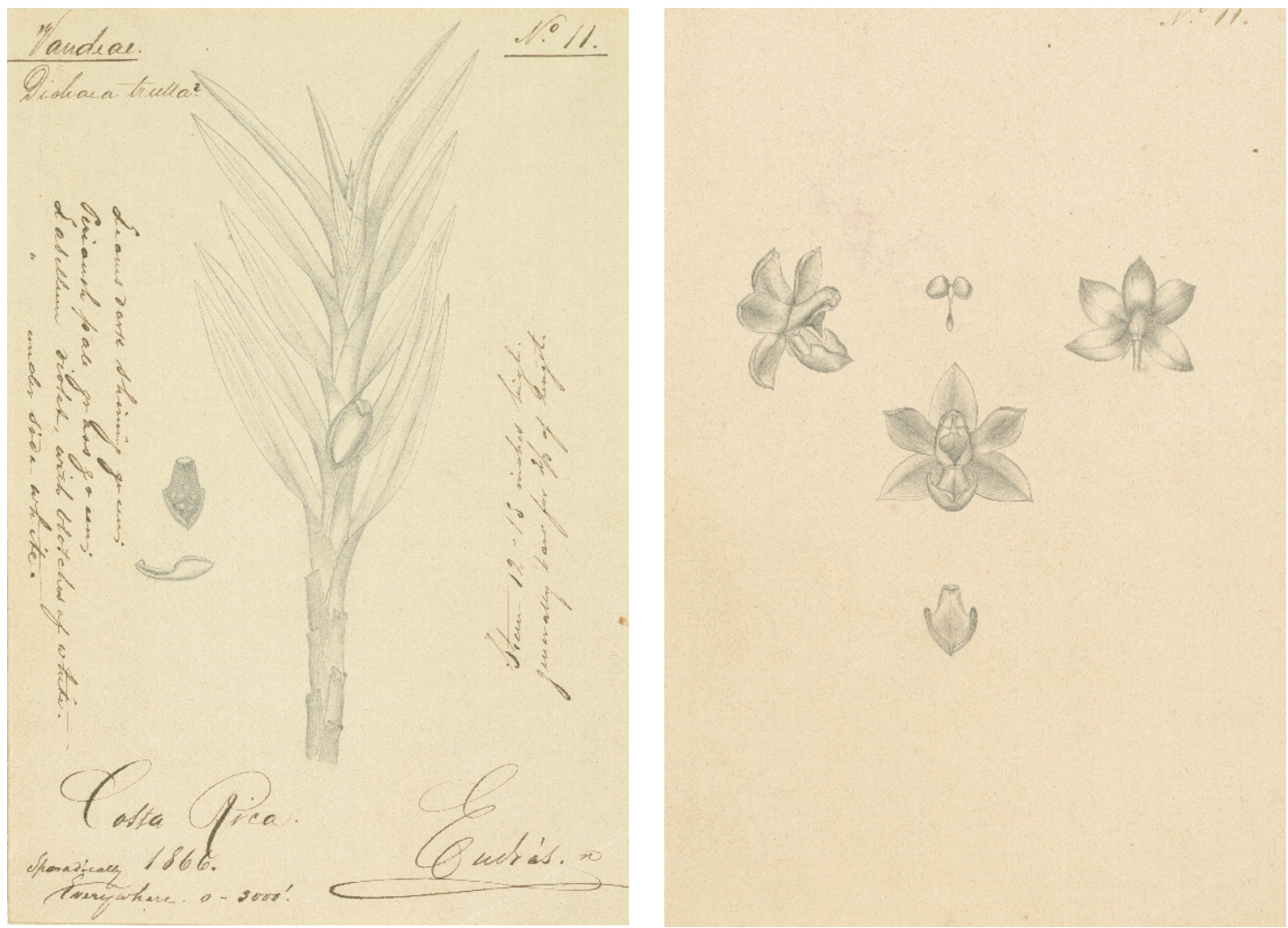

Figure 5. Dichaea trulla Rchb. f. (W Rchb-Orch 18037/W 0019163). Endrés first known collection of a orchid in Costa Rica.

of time and labor to collect anything here" as he wrote to Dow (Endrés, 1867). He was under the impression that the collectors who had visited the country before him had already taken "all that could be found within the country". It is fortunate that he apparently changed his mind. In the years to come, Endrés traveled throughout Costa Rica, reaching every region that was accessible at that time. The exceptions where the North and Northwestern regions (the westernmost part of the province of Alajuela and the region of Guanacaste), where orchids were large in quantity but small in diversity (and thus of little interest to Endrés), and the Pacific and Atlantic coastal regions of Southeastern Costa Rica, practically inaccessible at that time and only partially surveyed during the last two decades of the 19 century by explorers like the American geologist William Gabb, Archbishop Bernard A. Thiel, and the Swiss naturalist Henri Pittier. One of the smallest Central American countries, Costa Rica had in 1868 just about 128,000 inhabitants (Paniagua, 1943:
44). Large portions of the country were still covered by virgin forests that were fertile ground for plant collectors. As an example, Endrés wrote on one of his herbarium specimens (Ornithidium, W Rchb-Orch 35997/0018715), that it could be found "by thousands, north of Santa Maria."

The 'NeAR EAst': THE ROAD to Turrialba, the Turrialba volcano, Turrialba and surroundings (1867 AND SECOND HALF OF 1872). — The region of Turrialba was the first to be explored in Costa Rica by Endrés (Fig. 6). As he wrote to Spencer F. Baird, "In June 1867, I left a jar of Hummers [=hummingbirds] preserved in spirits, at the "Angostura..." (Endrés, 1869). He referred to the small village of Angostura, just East of the city of Turrialba, and to his activities as collector of birds, which he alternated with his main objective, the orchids. There is a list of birds at the United States National Museum, all collected by Endrés in Costa Rica. Of these, we find 37 specimens 


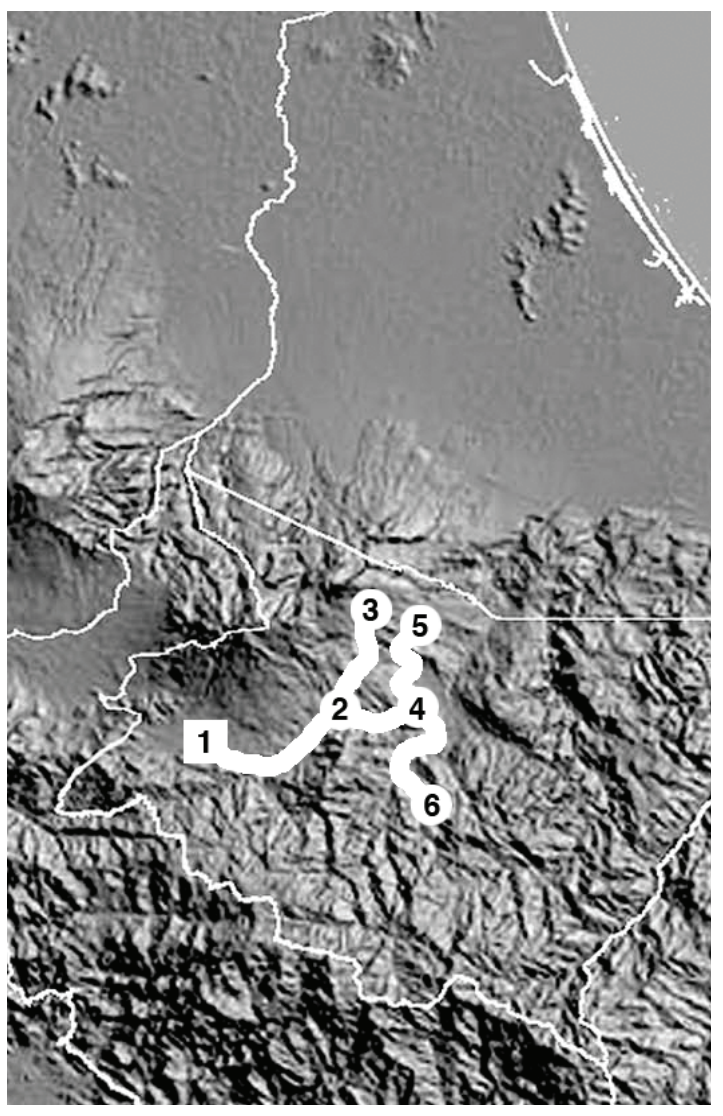

FIgURE 6. The 'near East': the road to Turrialba, the Turrialba volcano, Turrialba and surroundings. 1 - Cartago. 2 - Juan Viñas. 3 - Turrialba volcano. 4 - Turrialba. 5 Santa Cruz. 6 - Pejibaye.

of hummingbirds (Family Trochilidae) and one specimen of jacamar (Family Galbulidae). Two of the hummingbird specimens were described by Lawrence as new species: Eupherusa nigriventris (Fig. 7) and Glaucis aeneus. Others proved to be new records for the fauna of the State, in the words of Baird (1869).

He would return to the area some years later. In a letter to Dow of September, 1872, he wrote that he had "lately scaled the Volcan de Turialba" (Endrés, 1872). It is probable that this excursion to the volcano was part of his failed excursion to Talamanca, which took place in May of 1872. Also possible is that Endrés stayed on that occasion (May-September 1872) for a longer period of time in the area of Turrialba, traveling and collecting in the neighborhood of that city.

On his way to the volcano, Endrés must have stopped at the house of Eusebio Ortiz, a place which he had visited before and that is mentioned frequently on his herbarium labels, described by Endrés as follows: "Sitio [site] de Eusebio Ortiz. Southwestern slopes of Vulc. Turialba. Road from Cartago to Turialba. After crossing the river Birris, where the same gentleman possesses a saw-mill, one takes the cuesta [steep incline on a road] (Iglesias' new road) and before reaching the height, follows on the left until reaching the Potrero [pasture] where a house is found at a altitude of about 5,000 feet" (Endrés, 1869b). On the road from Cartago to Turrialba, Endrés collected in Paraíso, Cervantes, Birrís, Quebrada Honda, Naranjo, Juan Viñas, Chiz and Colorado. To the North of Turrialba he names Guayabo. To the Southeast we have seen labels from Atirro, Bóveda, and Angostura, where he probably stayed at the house of the German teacher Karl Lammich (Lammich had arrived at Angostura as part of the group that attempted to establish a German colony under the direction of Baron Alexander von Bülow. The attempt ended in 1854 as a total failure and most Germans abandoned the area, but Lammich stayed behind and lived for years at Angostura). To the South and Southeast he was in Pejibaye, Azul and Tucurrique, connecting from there again through Guatuso and Tejar with the southern part of Cartago and the road to San José.

The 'Far' East: the Atlantic Region (May 1872). Endrés excursions to the Atlantic region had probably the city of Cartago as their point of origin (Fig. 8), and were related to the construction of the railroad from San José to Puerto or Port of Limón. In October of 1872 Endrés wrote to Dow about his intention of forming a collection of plants with the help of Wilhelm Nanne (then in charge of the construction of the railway) and said he hoped that "he may give the necessary instructions to his staff of engineers for the purpose". Endrés was also offered to take part in the exploration of the region of Talamanca by W.M. Gabb (1839-1878, an American geologist who was hired in 1873 by Minor Keith, the builder of the railroad to Limón, to explore the region of Talamanca in search of the legendary gold mines of Río la Estrella and Tisingal, "for the purpose of working out a report on the vegetation of the eastern coast". And speaking of Talamanca, he wrote that "Last May [1872] already, I started in that direction but was dissuaded before I reached Limon" (Endrés, 


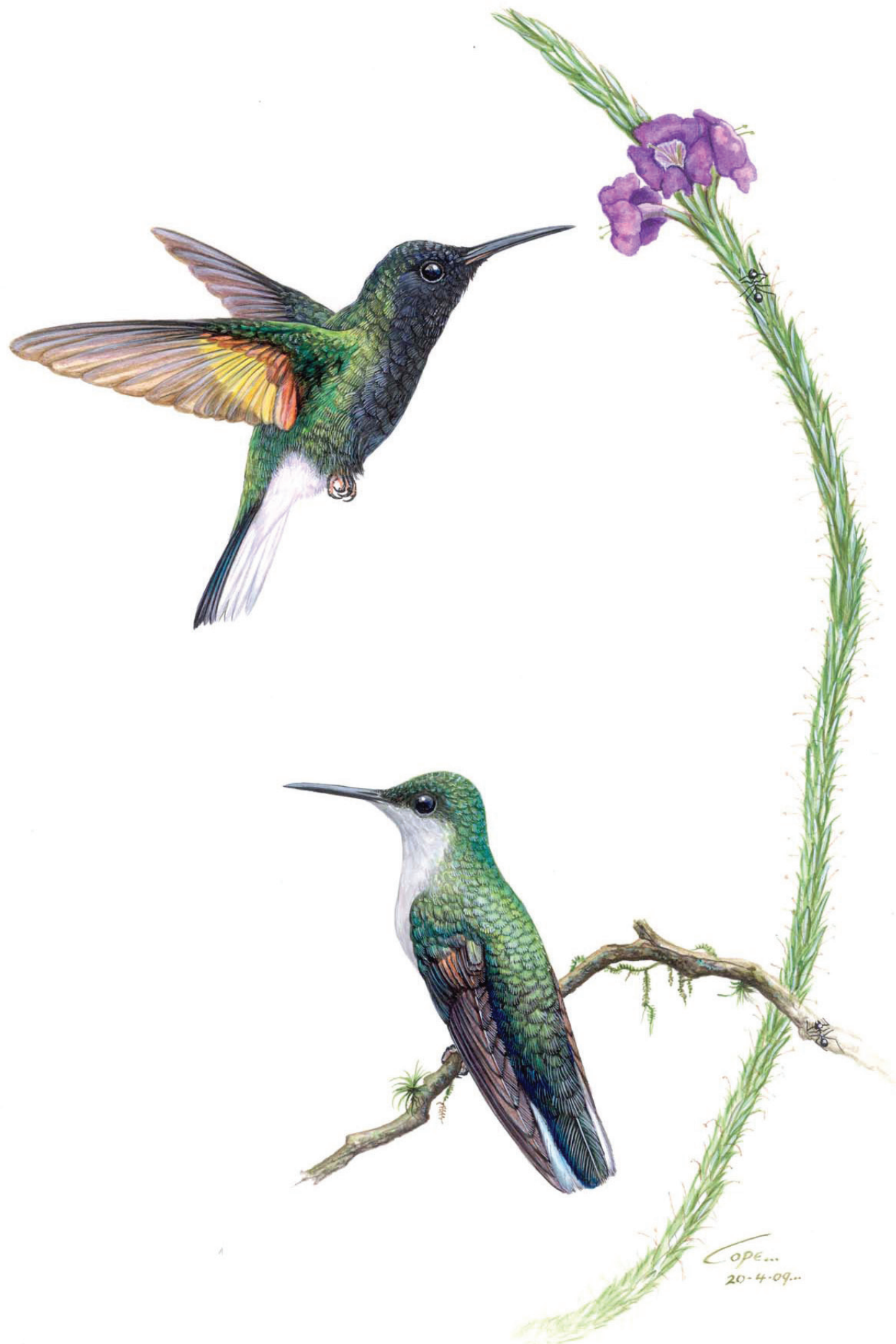

FIgURE 7. Eupherusa nigriventris Lawrence. A new species of hummingbird coollected by Endrés. Illustration by José Alberto Pérez Arrieta. 


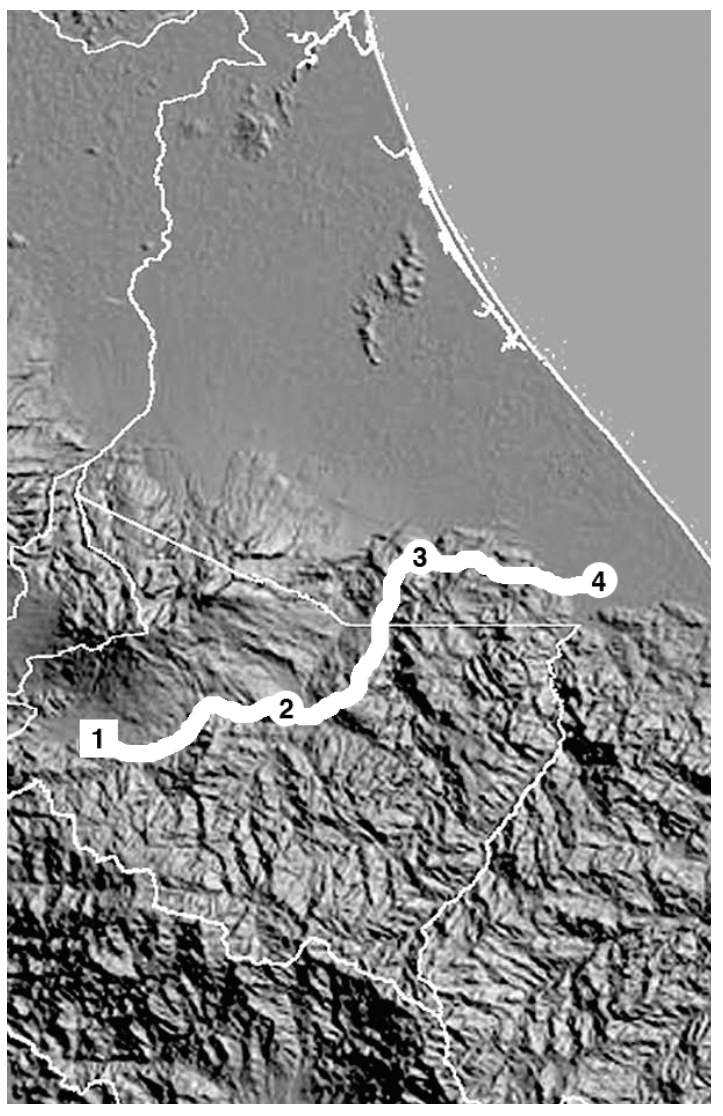

Figure 8. The 'far' East: the Atlantic Region. 1 - Cartago.

2 -Turrialba. 3 - Siquirres. 4 - Matina.

1872b). It was undoubtedly during this excursion that he met Georg Müllner at his Hacienda Caño Seco, and Müllner's hospitality which earned him the dedication of Lepanthes muellneriana (an unpublished name by Endrés for Lepanthes candida Endrés ex Luer; W Rchb-Orch 7618/W0019675, Fig. 9). Müllner and his partner, another German by the name Schäfer, had held important positions in the railway company (Bovallius, 1974) and it is therefore probable that it was Nanne, who was directing the construction of the railway, who referred Endrés to Caño Seco. Nanne was rewarded with the dedication by Endrés of Lepanthes nanneana (a manuscript, unpublished name for Lepanthes bradei Schltr.; W Rchb-Orch 7620/W0019685, Fig. 10).

It was in preparation of his excursion to Talamanca that Endrés read Valentini's manuscript about the discovery and conquest of the Atlantic region of

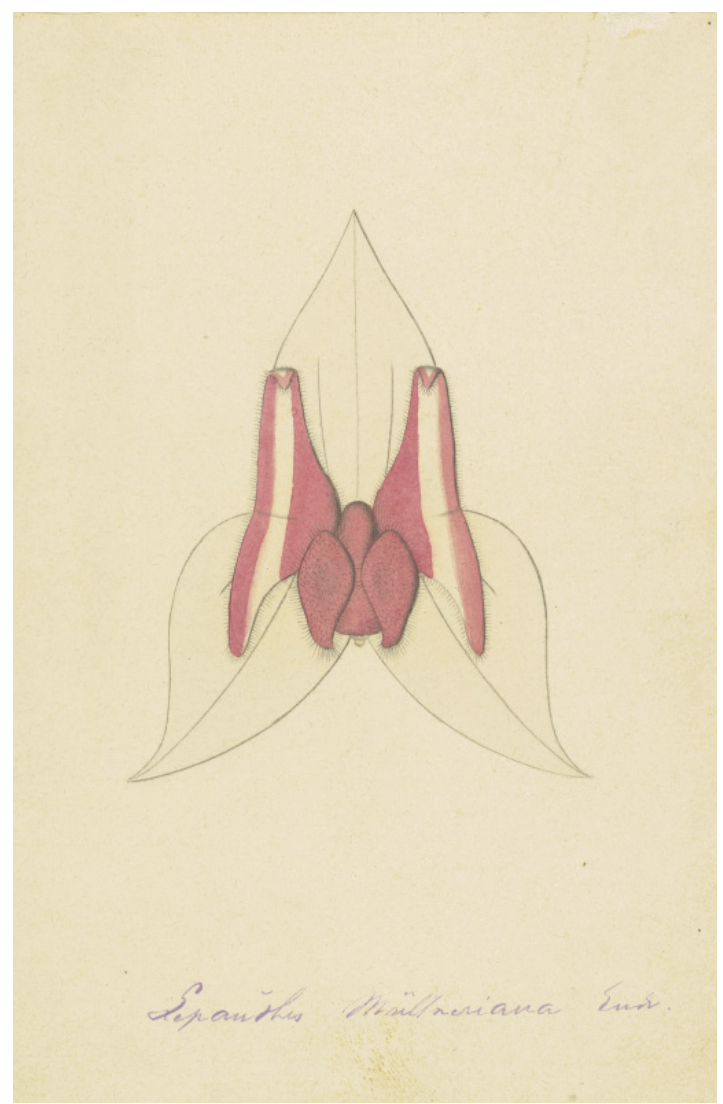

FIGURE 9. Lepanthes muellneriana [= Lepanthes candida Endrés ex Luer] (W Rchb-Orch 7618/0019675). Dedicated by Endrés to Georg Muellner, his host at Hacienda Caño Seco.

Central America (Valentini, 1869) and Wagner and Scherzer's famous book about Costa Rica (Wagner and Scherzer 1856). A reference to these works is given by Endrés in his 'Notizbuch II' (Endrés, 1870). Endrés extracted from Wagner and Scherzer a vocabulary of words of the Bribrí language (spoken by the natives of Talamanca), with its translation into German. Several specimens of Ionopsis, one of them bearing the label 'Common in Atlantic coast betw. Pacuare \& Matina in the Cacao haciendas del "Bejuco", (W RchbOrch 35959/W0019741) were collected during that excursion. Moreover, many of his collections on the route from Angostura to the Atlantic ocean are labeled "May", which is coincident with the indication in the above mentioned letter (Endrés, 1872b). Finally, in his letter to Endrés of October1872, Captain Dow wrote: "I am also glad to hear you have got some first [orchids] 


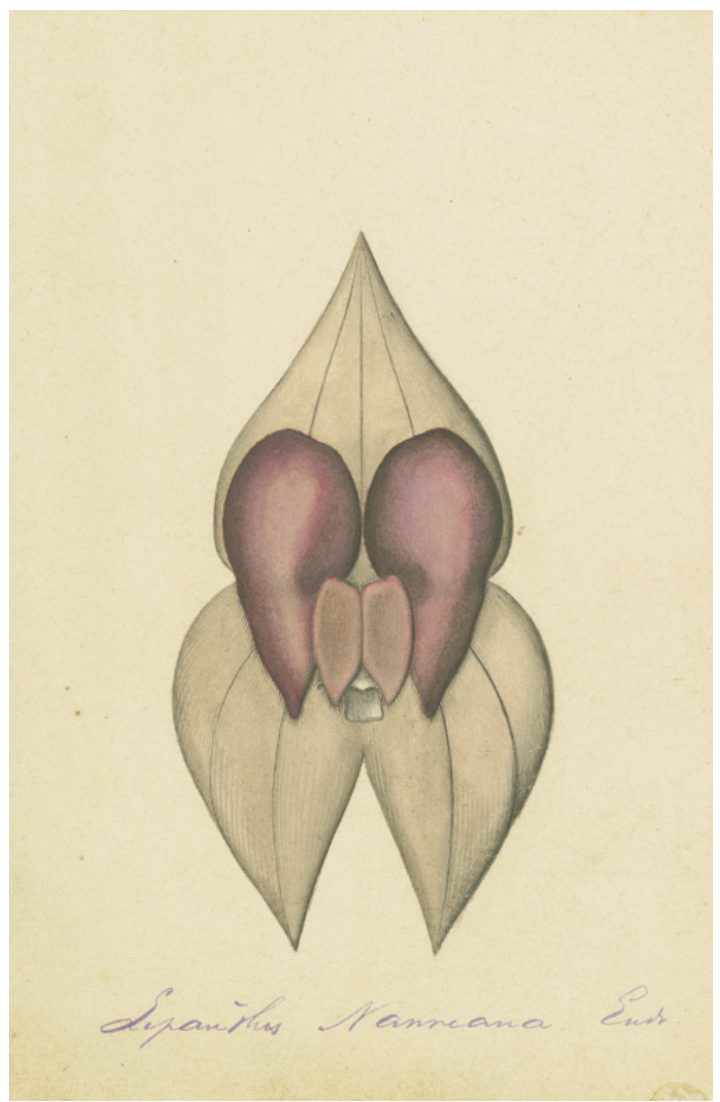

FIGURE 10. Lepanthes nanneana [= Lepanthes bradei Schltr.] (W Rchb-Orch 7620/0019685). Endrés' tribute to Wilhelm Nanne.

from the rivers of the eastern slope of the Cordillera" (Dow, 1872b). Molina had described the road to Matina as "extremely laborious", having to pass through large rivers without bridges, and large swamps. One had to rent horses in Cartago and ride through Turrialba to the Matina river, and take boats from there to the mouth of the river on the Atlantic shore. The journey took almost a whole month (Molina 1851).

Although the locality of Fajardo (near Ujarrás, on the Reventazón River) lies on the original route which was proposed for the railroad, we do not know if Endrés' orchid collections in that area (Fajardo, Ujarrás, Orosi) were made during the excursion sponsored by W. Nanne or on a different occasion. Let us remember that the railroad was originally planned to run along the Eastern bank of the Reventazón, but the rocks of Fajardo proved to be an insurmountable

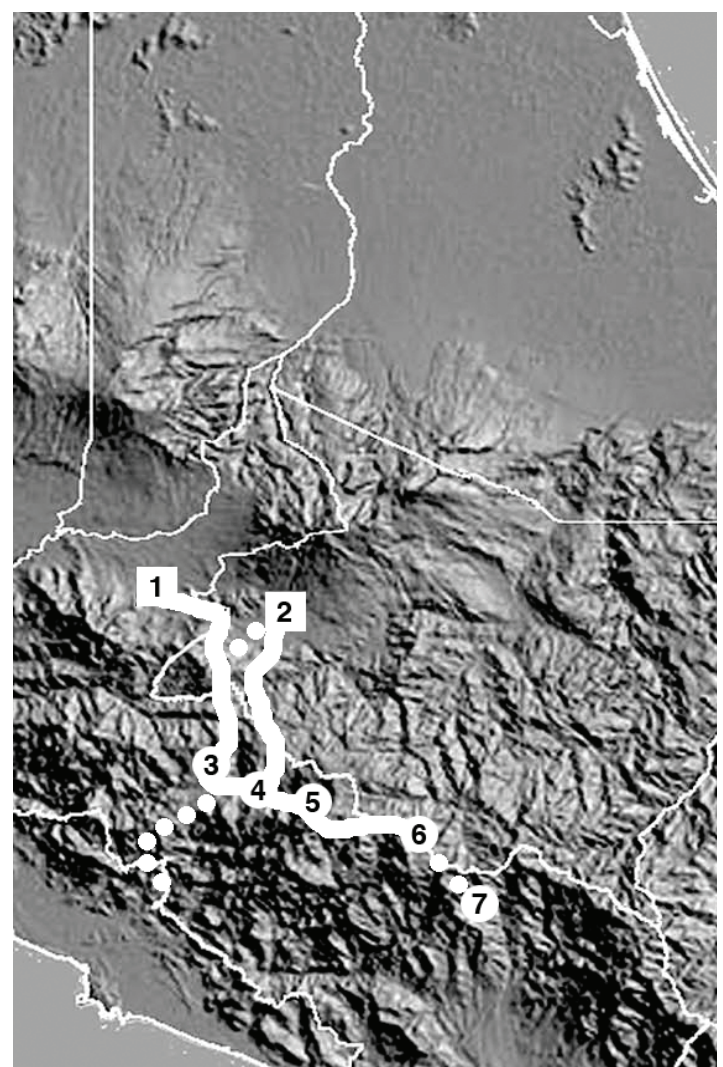

FIgURE 11. South and Southeast of Cartago, the ascend to the Páramo de Vueltas and Cerro Buena Vista, and the 'new' road to Térraba. 1 - San José. 2 - Cartago. 3 - San Pablo. 4 - Copey. 5 - Cerro Vueltas. 6 - Cerro de la Muerte. 7 - División.

obstacle. The route was afterwards changed to the Western bank of the river, running from Cartago to Cervantes, Juan Viñas and Turrialba.

South and Southeast of Cartago, the ascent to the Páramo de Vueltas (also called Páramo de Dota) and Cerro Buena Vista, and the 'New' road TO TÉrRABA. - There were two routes into the Talamanca mountain range (Fig. 11). The first went from San José through Desamparados and Tablazo to Corralillo and Frailes, and from there to Boca de Dota (named also Atarrazú, today the city of San Marcos de Tarrazú). In Tarrazú there is frequent mention by Endrés of the "savannas of Ramón Zúñiga". Ramón Zúñiga Barahona had been one of the founders of the village and probably another of the many people whose hospitality was enjoyed by Endrés during his 


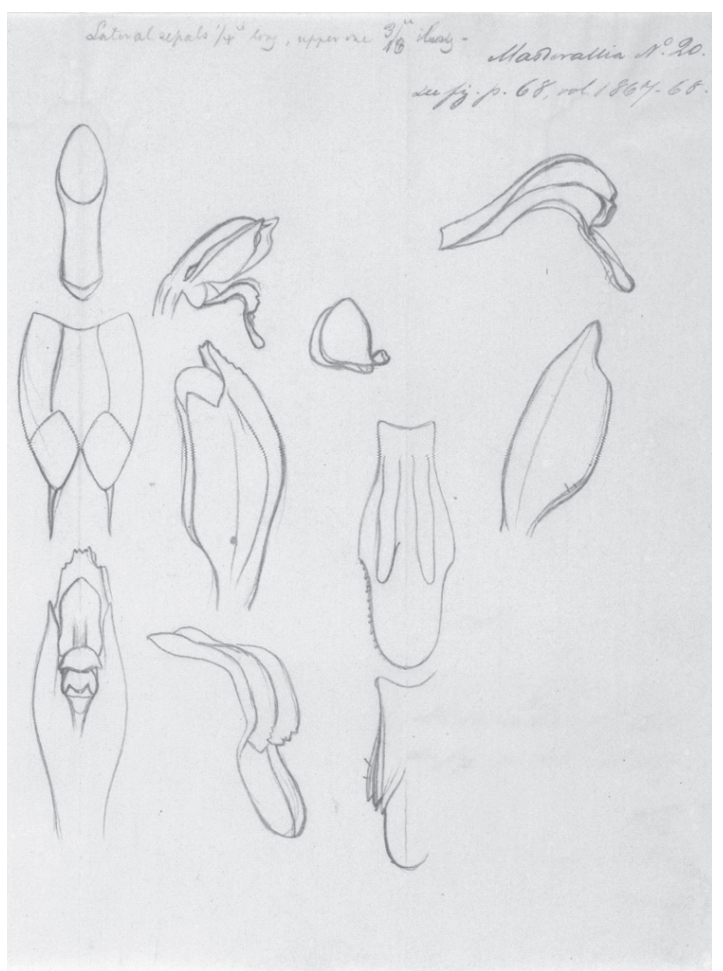

FIgURE 12. Masdevallia [= Scaphosepalum mycrodacylum Rolfe] (W Rchb-Orch 38548/W0020768). Collected by Endrés in Atarrazú.

travels. Santa María de Dota was founded somewhat later by settlers who came from Tarrazú and from there a road was built to the hamlet of Copey.

The second route started from Cartago, and went through El Tejar, were Endrés mentions the lime-kilns of Ana Cleta Mayorga [1809-1877, a rich widow, owner of an important coffee farm near Paraíso, and one of the first women in Costa Rica who took an active part in politics (Gutiérrez Braun, 1981)], passed near Pizirres (where he stayed at the house of Rafael Calderón) and went on to Estrella and Copey, following more or less the course of the present PanAmerican Highway.

Both routes interconnected through the road from Cartago through Tobosi to Corralillo, and Endrés mentions a number of different localities in this area in his collections, such as Copalchí, Alumbre and the road to Palo Blanco.

From the indications on his herbarium sheets, it seems that Endrés traveled both of the routes to

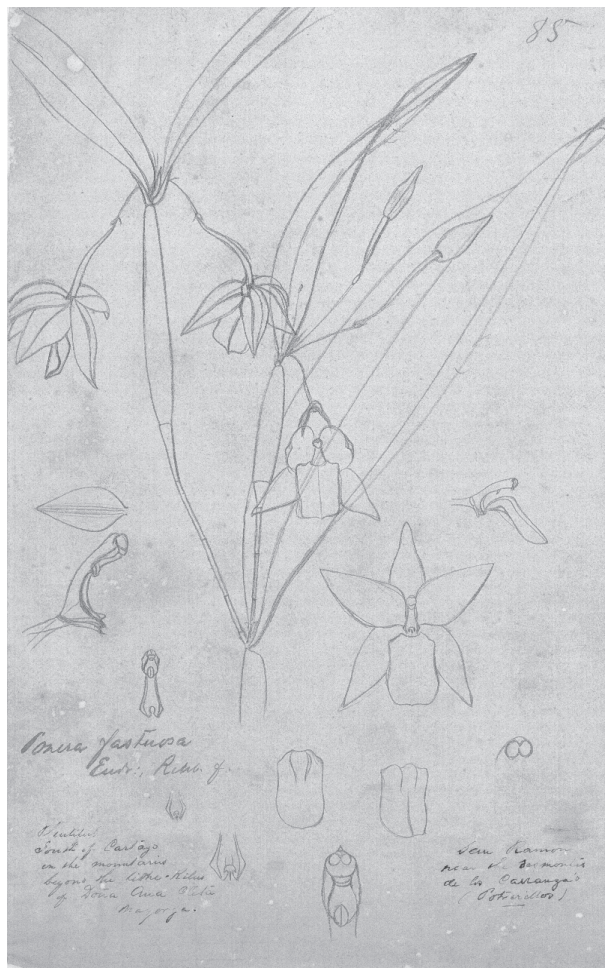

FIgURE 13. Ponera fastuosa [= Scaphyglottis pulchella (Schltr.) L.O.Williams] (W Rchb-Orch 33226/ W0020722). Collected by Endrés on the road from Cartago to San Cristóbal and Copey.

the region of Dota. From the first, Endrés recorded Masdevallia (= Scaphosepalum microdactylum Rolfe; W Rchb-Orch 38548/W0020768, Fig. 12) and Trichocentrum saundersianum (= Trichocentrum pfavii Rchb. f.; W Rchb-Orch 37148/W0020946), while from the route to Copey he gathered Ponera fastuosa (= Scaphyglottis pulchella (Schltr.) L.O. Wms.; W Rchb-Orch 33226/W0020272, Fig. 13) and Platystele propinqua (Ames) Garay (W Rchb-Orch 38623/W0020363).

From Copey, Pedro Calderón started, in 1866, to explore a trail across the mountains, trying to reach the Valley of El General and the region of Térraba. Calderón, a native of San Ramón, was accompanied by his son-in-law Juán López. While Pedro Calderón spent months at a time in the mountains, his son-in-law returned every three months to San Ramón, to visit his family, a journey of over two weeks each way. It may well be that Endrés learned about this area from Juan López, and that he decided to travel with him when 


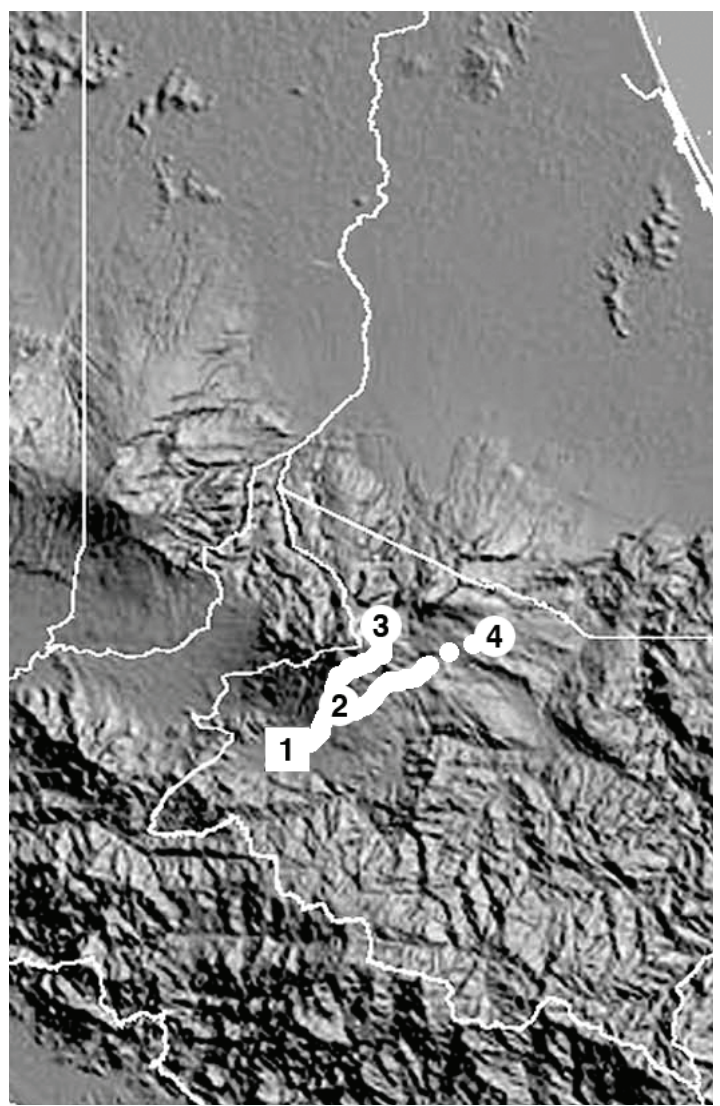

FiguRE 14. North of Cartago: the slopes of the Irazú volcano.

1 - Cartago. 2 - San Rafael. 3 - Irazú volcano. 4 - Santa Cruz.

he returned to the mountains. Calderón and López received shelter and supplies from Patricio Granados, a landowner in Copey who is often named (as "the savanna de los Granados") by Endrés on his labels. Endrés makes specific mention on one of his labels (W Rchb-Orch 38502/W0019335, Fig. 18) of Calderón's trail (the 'Picada de Pedro Calderón') and on several of his specimens from Dota mentions 'the [new] road to Térraba', not to be confused with the "old road to Térraba”, which went from Tarrazú on a south-westerly course to the Pacific plains in the neighbourhood of Quepos. Endrés traveled on the first part of this "old" road and collected as far as Cerro Pito (see, among others, W Rchb-Orch 38627/W0021719).

North of Cartago: the slopes of the Irazú volCANO. - Although no exact date is known for his excursion, Endrés collected on the slopes of the

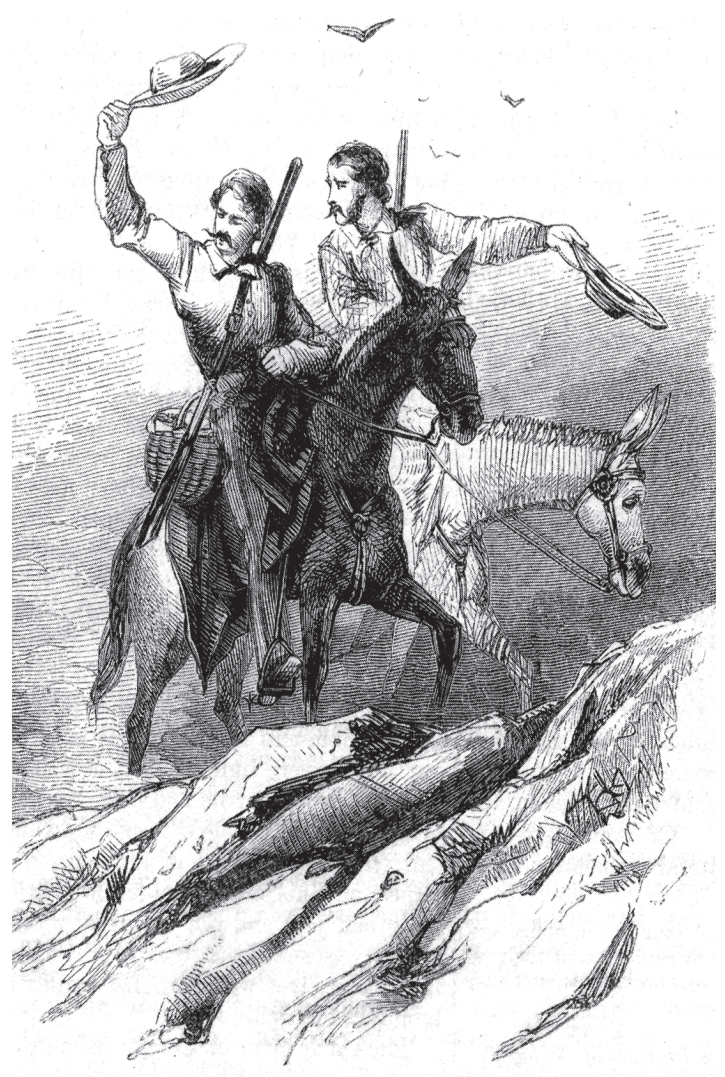

FIgURE 15. Ascent to the Irazú volcano. In Vargas, 2008.

Irazú volcano (Fig. 14-15). In his description of the flora of the Turrialba volcano, he writes to Dow (Endrés, 1872): “... yet the flora is much the same as that of the contiguous Volc. Irazú, interspersed with a few sp. from the crest of Dota." Clearly, he had been on the Irazú and in Dota before ascending to the Turrialba. Endrés names several collecting localities in this area: Cot, Potrero Cerrado, Pascón (near Pacayas), 'Felipe Díaz' (a Spanish conqueror, who in 1569 had been granted a large part of Cot and its neighborhood) and Cerro Grande (W Rchb-Orch 38538/W0019322; W Rchb-Orch 36720/W0021668; and many others).

The Northwest: SAN RAmón AND SURroundings AND the RoAd to San Carlos (1867-1874). — The town of San Ramón was not only the favorite collecting area for Endrés, but for most of his time in Costa Rica also 


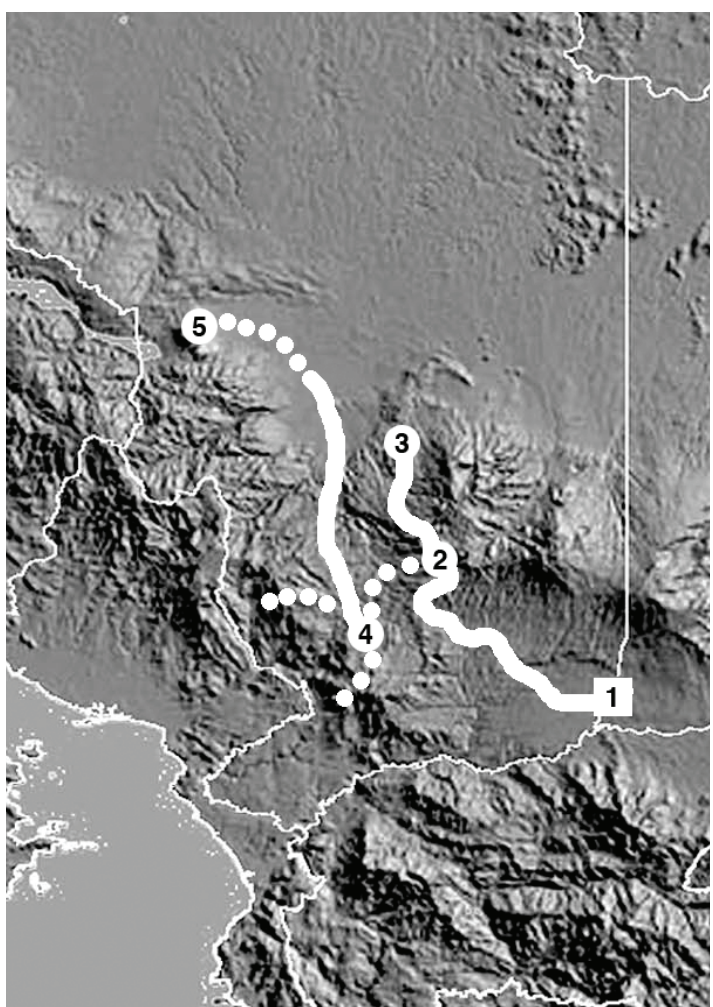

FIgURE 16. The Northwest: San Ramón and surroundings and the road to San Carlos. 1 - Alajuela. 2 - Zarcero. 3 - Ciudad Quesada. 4 - San Ramón. 5 -Arenal Volcano.

his place of residence (Fig. 16). From his letters to Captain Dow and Prof. Baird we know that he lived in San Ramón at least from November 1867 until April 1874. In September of 1872 he even bought a piece of property in the center of the town (Archivos Nacionales, 2008; Fig. 17). At least four herbarium specimens with collecting localities close to San Ramón (Quebrada Verde, Cerros de los Palmares) are dated in 1867, a clear indication that this area was explored by Endrés from the very beginning of his stay in Costa Rica.

Endrés first came to San Ramón in the last half of 1867 , after he was named superintendent for the construction of the road to San Carlos, which led from the district of Los Ángeles (to the North-Northwest of San Ramón) to the Cataratas River and from there to the "navigable waters of the San Carlos River" (Endrés, 1869). This is the route which Endrés calls "the road to San Carlos" or "the new road to San Carlos". However, in a few cases Endrés mentions "the

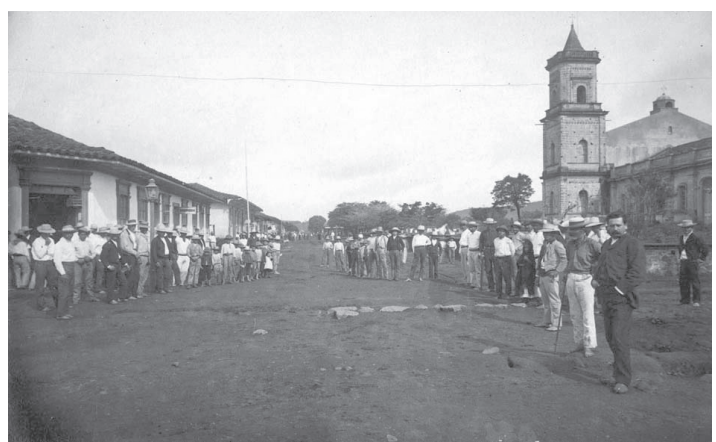

Figure 17. San Ramón, ca. 1880. Courtesy of Álvaro Castro H.

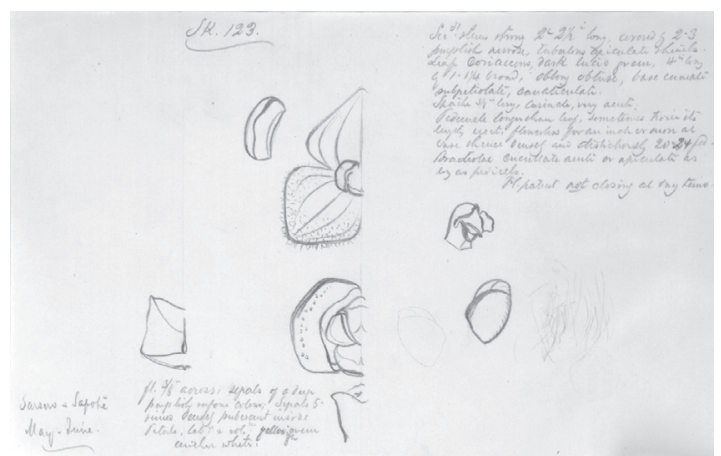

FIGURE 18. Stelis argentata Lindl. (W Rchb-Orch 142213/

W1889-0142213). Collected in Zarcero, along the 'old' road to San Carlos.

old road to San Carlos". This road went from Alajuela to Grecia and passed through Zarcero, Zapote and the La Vieja River. It had been opened in 1850 by the expedition of Martínez and Toledo and was of military importance during the campaign of 1856 against the troops of William Walker (Hilje, 2008). After the war, it was abandoned. In Endrés' time it must have been no more than a trail (W Rchb-Orch 142213/W18890142213; Fig. 18).

Living in San Ramón, Endrés could travel in any direction and find undisturbed forests, ideal for his purposes. Journeys of no more than 1-3 days brought him to the North, to the hacienda of Ramón Rodríguez Solórzano (one of the founding fathers and the first mayor of San Ramón) at Silencio, the ford at the San Lorenzo River, to Quebrada Verde (near Balsa), and reaching as far as the headwaters of the San Carlos River. The trail to San Carlos, at the ford of the San Lorenzo River, was also known as 'picada de Nelson', or 'Nelson's path', and Endrés mentions the house of 


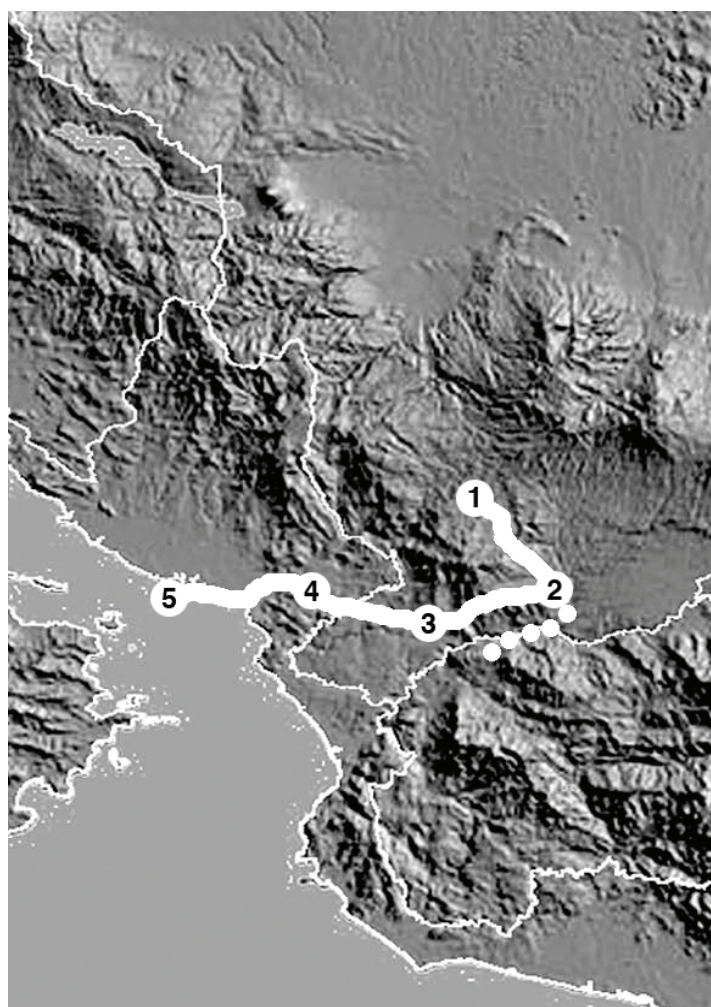

Figure 19. The West: the road from San Ramón to

Puntarenas. 1 - San Ramón. 2 - Atenas. 3 - San Mateo. 4 - Esparza. 5 - Puntarenas.

P. Nelson in this area. His incursions to the Arenal Volcano (called at that time 'Cerro de los Guatusos') were surely coincidental with his travels during the construction of the road to San Carlos.

To the Northeast, passing through the hacienda of Julián Volio (the village of Volio of present days) he collected in Zarcero, Palmira, Laguna, Zapote and Tapezco. A note in his "Notizbuch II" (Endrés, 1870) reads "Sarcero, June 10th, 1871". To the Southeast we have seen specimens from Palmares, Candelaria, San Roque and Grecia. To the Southwest he collected in Río Jesús and the lime-kilns of La Calera. To the South he described plants from Dujardin's Hacienda La Francia and to the Northwest from La Paz, Potrerillos, and the rivers Piedras and Barranca. Near Potrerillos he mentions the "lands of Teresa Rodríguez", meaning undoubtedly Teresa de Jesús Rodríguez Vega, the widow of Pioquinto Alvarado Arrieta (1816-1843), another of the founding fathers of San Ramón.

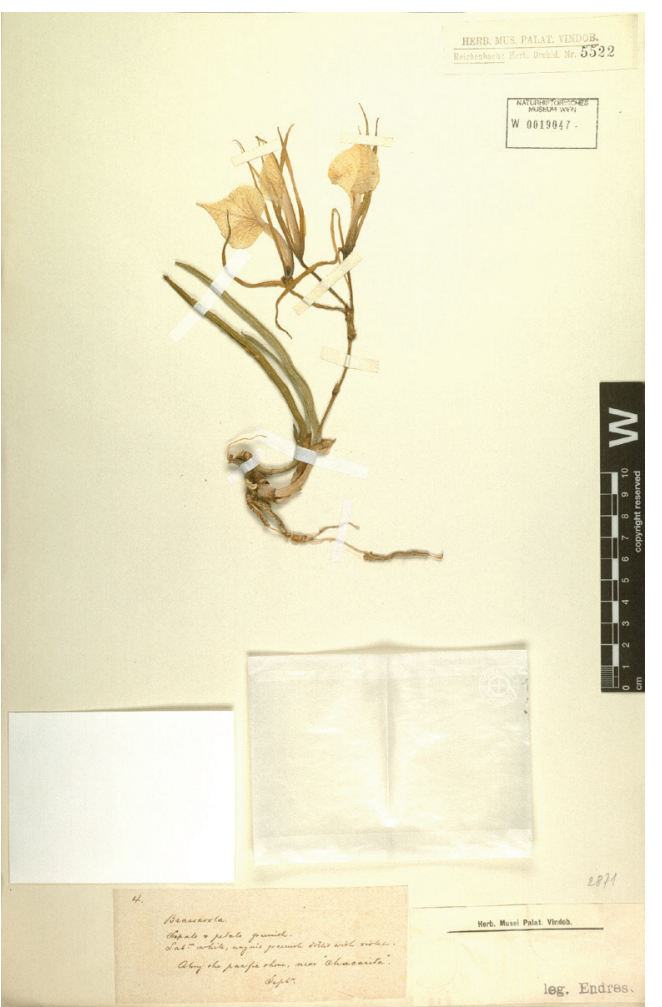

Figure 20. Brassavola nodosa (L.) Lindl. (W Rchb-Orch 5522/W0019047). "Along the Pacific shore, near Chacarita."

The West: the road from San Ramón to Puntarenas. - The 'National Road', connecting the capital city of San José and the port of Puntarenas, on the Pacific, was built between 1844 and 1846 and was the only road apt for oxcarts in Central America at that time. Although Endrés probably could have found a shorter route to Puntarenas, it seems clear, from his letters, that he traveled always first to Atenas (through Palmares and Candelaria), and then on the National Road to San Mateo, rivers Paires and Jesús María, Esparza, Barranca and Chacarita until reaching the harbour (Fig. 19). All of these places are well documented on orchid collections by Endrés, who still uses for this road the name "Camino Real" [Royal road] from Costa Rica's colonial times (i.e., W RchbOrch 38586/W0020193; W Rchb-Orch 5522/ W0019047, Fig. 20). Other collecting localities of Endrés near this route are Río Grande, Balsa and Picagres. 


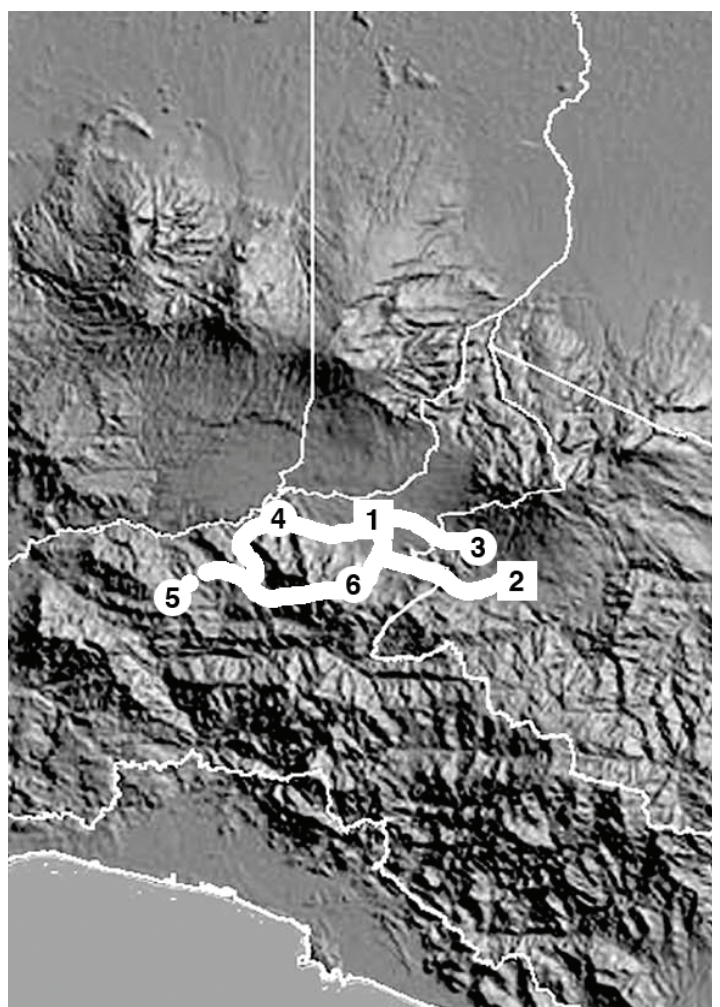

Figure 21. South, Southeast, and Southwest of San José. 1

- San José. 2 - Cartago. 3 - Tres Ríos. 4 - Santa Ana. 5-Santiago. 6-Aserrí.

His visits to Puntarenas had seemingly always the same purpose, which was to meet his friend and mentor Captain John Melmoth Dow, but this route was also important for Endrés because it was via Puntarenas that he received his mail and that he sent his plants and herbarium specimens.

South, Southeast, and Southwest of San José. - There are no documents to tell us when Endrés collected in this area. According to L.D. Gómez (pers. comm. 2006), we assume that, in the first months of residence in Costa Rica, he lived for some time in San José, and this may have been the time to explore the surroundings of the city (Fig. 21). He could have taken the route to Aserrí and from there to Tabarcia and Pacaca exploring on the way the mountains of Tablazo and Cerro del Dragón (all named on his herbarium labels: W Rchb-Orch 36218/W0019352, Fig. 22). He also collected on the hills of Carpintera (to the East of San José) and Pico Blanco, to the Southwest. When

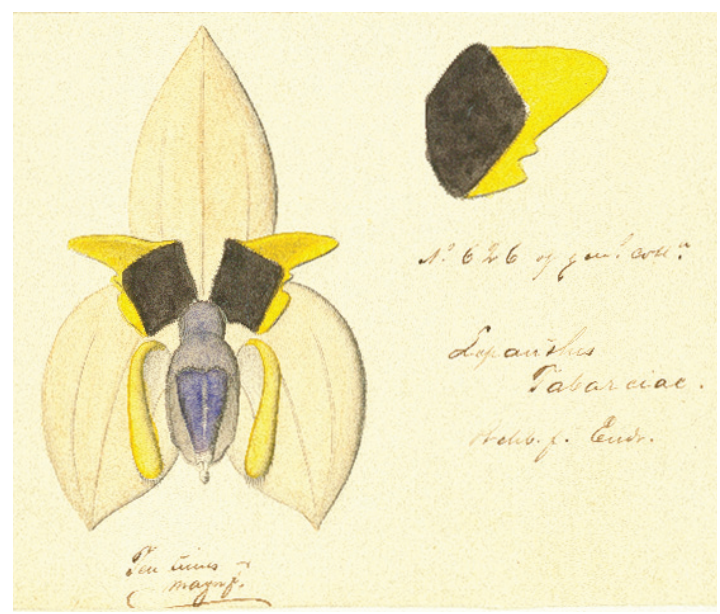

FIgURE 22. Lepanthes inescata Luer (W Rchb-Orch 36218/ W0019352). Named by Endrés Lepanthes tabarciae, after the village of Tabarcia, southeast of San José.

travelling from San José to Cartago, Endrés seemingly always used the old colonial road, from San José to Desamparados and from there over Patarrá and Tobosi to Tejar and Cartago, thus traveling along the southern flank of the Carpintera mountains, rather than over the 'modern' road through Tres Ríos. This road was known as the "camino por lo alto" [road along the heights] or Cavallón's road [Juan de Cavallón y Arboleda (1524-1565) was a Spanish conqueror who in 1561 founded Garcimuñoz, the first Spanish city in Costa Rica's central valley, situated at the present location of Desamparados].

The Central Mountain Range (Poás and Barva volcanoes). - Again, we have no dates for Endrés' collections along the southern slope of the Central Mountain Range. However, he names frequently localities along the route to the Poás (also called by him 'Volcan de los Votos') and Barva volcanoes and seems to be quite familiar with that area (Fig. 23). San Isidro, Itiquís River, Desengaño, Poás and Barba are names which are often found on the herbarium specimens preserved in Vienna. Charles Lankester, who seems to have been familiar with Endrés' itineraries, wrote about Varablanca, a locality on the pass of Desengaño: "Endrés worked it, but probably mainly for horticultural stuff!" (Lankester, 1923). North of the village of Barva, Endrés seems to have been acquainted with Pío 


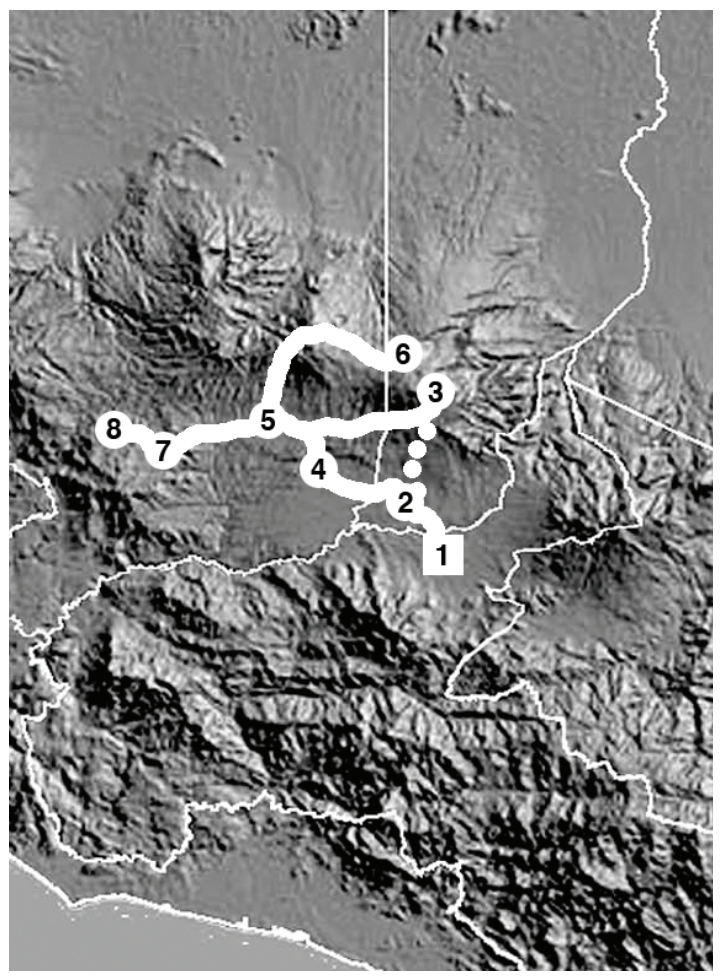

Figure 23. The Central Mountain Range (Poás and Barva volcanoes). 1 - San José. 2 - Heredia. 3 - Poás volcano. 4 - Alajuela. 5 - Sarchí. 6 - Varablanca. 7 - Palmares. 8 - San Ramón.

Murillo, the owner of a large farm close to the crater of the Barva volcano.

It is clear that Endrés was well acquainted with this region. One of his notes on a herbarium sheet preserved at Vienna (W Rchb-Orch 36911/ W0021520) reads: "Plenty of the Poas Sobralia along the road from Alajuela (Camino de las Canoas) to Desengaño, some 2,000 yds. above Casorla's Hacienda growing on the respaldos [embankments of the road] (terrestrial). Further up towards where the "Tambor" river crosses the road, Odontoglossum cariniferum with ovate oblong, [...] bulbs, ovate acute leaves and a 2-3 ft. long erect stout 50-60 fl. panicled peduncle and rachis somewhat glaucous. On the same spot a pendulous 8 in. long Epidendrum with lanceolate acuminate fleshy green leaves flat [...] behind. Flowers in a slender fine branched irregular short panicle, pale [...] lilac, spurred, small, inconspicuous. Sept. Oct. Among the Poas Sobralia, Fregea Batemanniana with deep purplish carmine

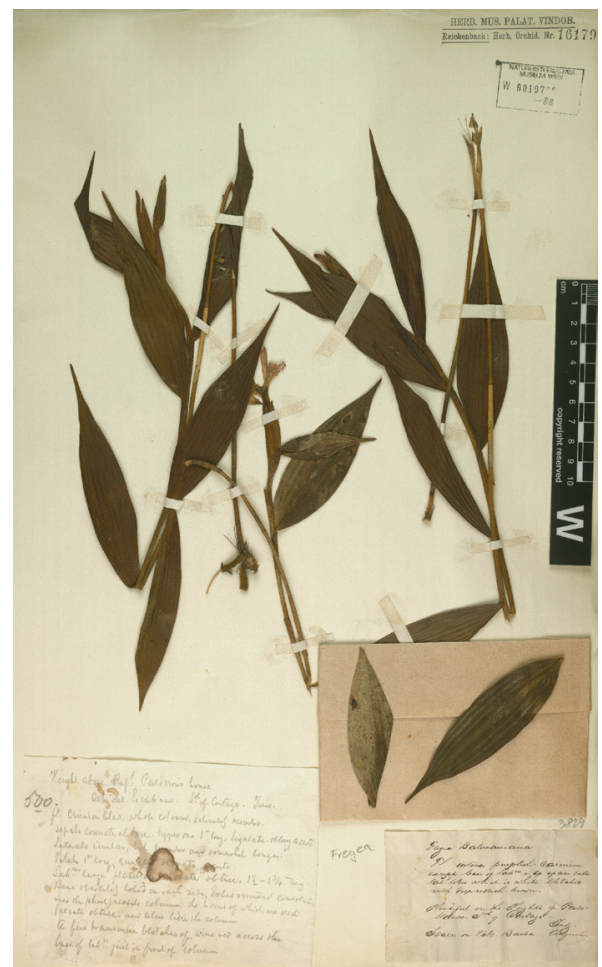

FIgURE 24. Fregea batemanniana [= Sobralia amabilis (Rchb.f.) L.O. Williams] (W Rchb-Orch 16179W0019788). Collected by Endrés on the southern slopes of the Barva volcano.

flower, the base of labellum white blotched with deep crimson. Above Santa Bárbara plenty of Epidendrum campylostalix, Odontoglossum pulchellum ? the Candelaria \& Poás variety. Above San Isidro (Alajuela) Epidendrum campylostalix, Lycaste candida, Odontoglossum pulchellum and some plants of Odontoglossum cariniferum (W Rchb-Orch 38546/ W0019496; Fig. 24).

A man named José Mora seems to have been Endrés' guide to the Poás volcano. In his Notizbuch II (Endrés, 1870) Endrés mentions a 6-day journey to the volcano, for which Mora was paid $\$ 4,50$ (Pesos, the Costa Rican currency of that time).

The journey of augustus R. Endrés to Panama. Endrés traveled to Panama sometime between May 1871 and April 1872 (Fig. 25). In September 1872 Endrés wrote to Dow from Puntarenas "for the first time since my visit to the isthmus have I come down to the port..." (Endrés, 1872), remembering his 


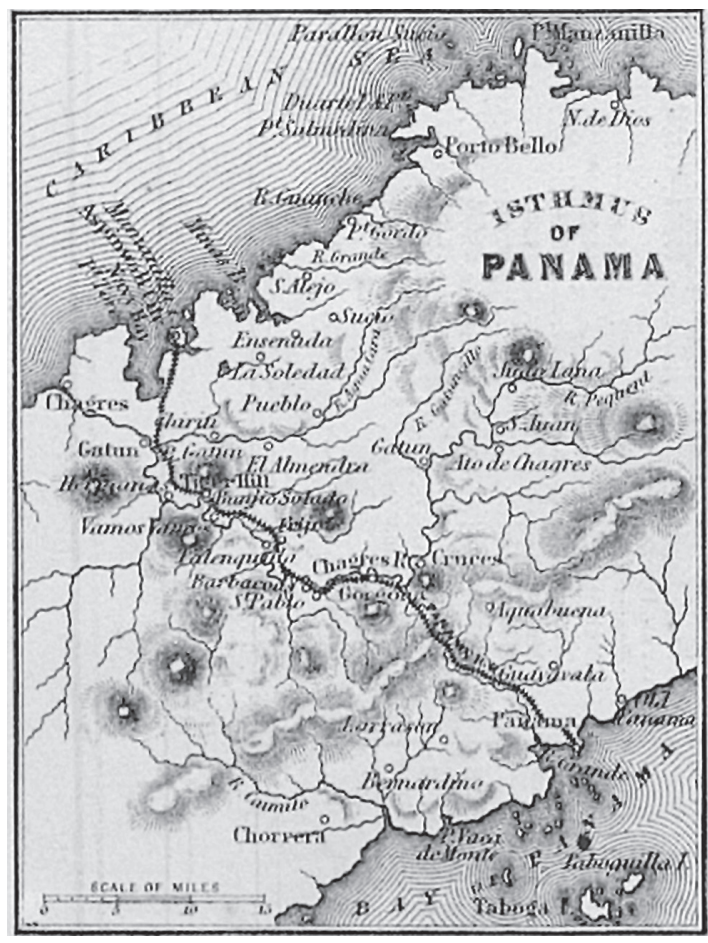

FiguRe 25. The journey of Augustus R. Endrés to Panama.

visit to Panama which had the purpose of delivering in good conditions to the transatlantic steamer a shipment of orchids to Veitch. As Dow wrote later to Endrés: "I am sorry the Messrs. Veitch were not satisfied with the remittance you took so much pain to accompany to Aspinwall" (Dow, 1872c). From his few collection dates, it can be assumed that he arrived in Panama sometime in June of 1871 and embarked for his return to Costa Rica on April 12, 1872. This means that he could have been as much as 10 months away from San Ramón. The main purpose of this trip was clearly not the collection of orchids, of which barely a dozen can be found in the archives of the NHMW (W Rchb-Orch 5547/ W0020710; Fig. 26).

Also, in Hortus Veitchii (Veitch, 1906), concerning Epidendrum lindleyanum, one reads: "The variety Centerae was introduced by us from Costa Rica, in 1873, through M. Endres; and dedicated to Mrs. Center, the wife of the then superintendent of the Panama Railway". Endrés was obviously familiar with Panama, the railway and its officials and the fact that Endrés had suggested

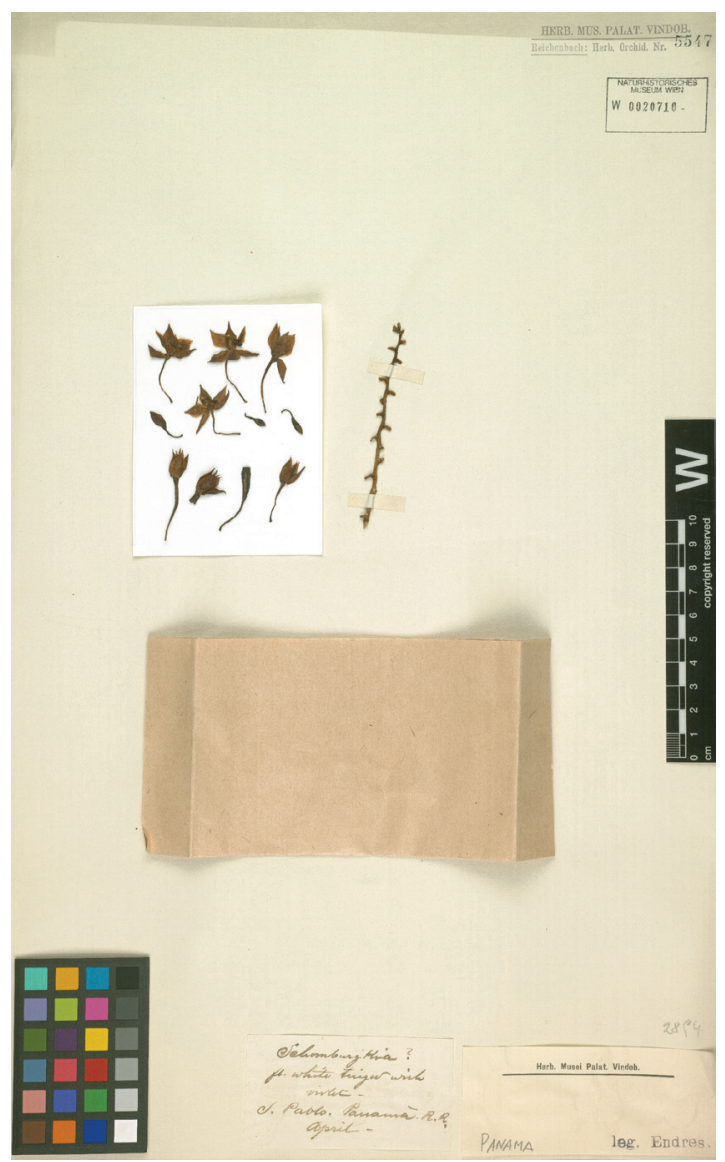

FiguRE 26. Schomburgkia [= Caularthron bilamellatum (Rchb. f.) R.E. Schult.] (W Rchb-Orch 5547/ W0020710). Collected by Endrés at San Pablo Station, Panama railroad.

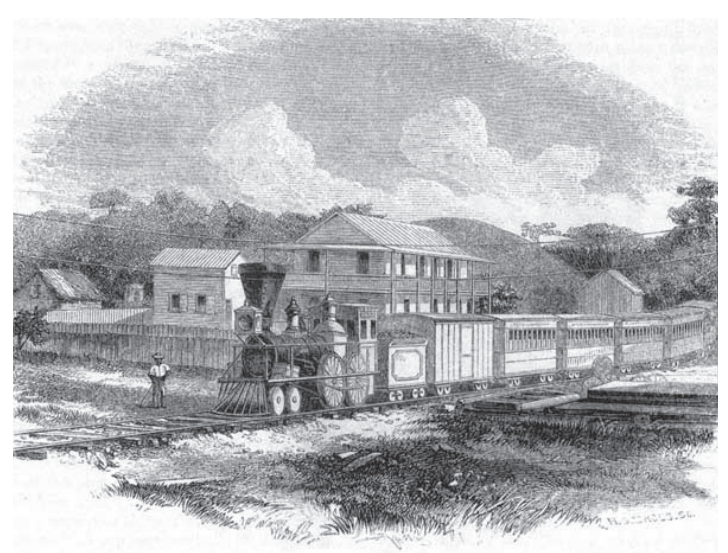

Figure 27. San Pablo Station, Panama Railroad. In Vargas, 2008. 
the name Restrepia centereana for the specimen of Restrepia trichoglossa collected by him, we presume that the superintendant's wife had made quite an impression on him.

We also presume that Endrés was using the railway to reach the eastern seaboard of Central America to sail home to Europe as there was no deep-sea port on the Atlantic coast of Costa Rica. One therefore wonders if the superintendant was aware of the honour subsequently bestowed on his wife by a passing stranger - if indeed he was just a passing stranger (Manning, 2008). The localities indicated by Endrés on his specimens are all referred to the railway, namely three of its stations: San Pablo (Fig. 27), Obispo, and Matachín.

Endrés introduction to Alexander Center and his family must again have been the work of John M. Dow. Dow was a good friend of the family. In April 1872 he wrote to his wife: “... knowing of my intimacy with the Center family..." and further on, in the same letter: "... so far as their society is concerned I would not ask for more agreeable company than they [Mrs. Center and her daughters] have proved themselves to be" (Dow, 1872).

\section{LiterATURE CITED}

Archives départementales du Bas-Rhin (in Strasbourg), 2010. Document 1TP/PRI374: letter from Philippe Endrés to the Prefect of the Department du Bas-Rhin, indicating that his son Auguste is living with his grandfather Auguste Reeb in New York at that time, July 18, 1857.

Archives départementales du Bas-Rhin (in Strasbourg), 2010a. passport application of Auguste Reeb from 1855.

Archivos Nacionales, Costa Rica, 2008. Protocolos Lara \& Chamorro, document CR-AN-AH-LYCH-000731T12-F60: purchase of a property in San Ramón by ‘Agustín' Endrés.

Atwood, J. \& D.E. Mora de Retana, 1992-1993. Orchids of Costa Rica. Icones Plantarum Tropicarum, Series I, Fascicles $15 \& 16$. Marie Selby Botanical Gardens, Sarasota, Florida.

Dow, J.M. 1872. Letter to his wife, April 12, 1872. John Melmoth Dow papers, \#2765. Division of Rare and Manuscript Collections, Cornell University Library.

Dow, J.M. 1872b. Letter to A. R. Endrés, October 12, 1872. John Melmoth Dow papers, \#2765. Division of Rare and Manuscript Collections, Cornell University Library.

Dow, J.M. 1872c. Letter to A. R. Endrés, November 15,
1872. John Melmoth Dow papers, \#2765. Division of Rare and Manuscript Collections, Cornell University Library.

Dow, J.M. 1873. Letter to George W. Clinton, President of the Buffalo Society, July 15, 1873. John Melmoth Dow papers, \#2765. Division of Rare and Manuscript Collections, Cornell University Library.

Baird, S.F., 1869. Letter to A. R. Endrés, March 23, 1869. Archives of the Smithsonian Institution, Washington D.C.

Endrés, A.R. 1867. Letter to Captain John M. Dow, May 25, 1867. John Melmoth Dow papers, \#2765. Division of Rare and Manuscript Collections, Cornell University Library. He writes that he has been recently in Greytown.

Endrés, A.R. 1869. Letter to Spencer F. Baird, January 23, 1869. Archives of the Smithsonian Institution.

Endrés, A.R. 1869b. 'Notizbuch I', one of the Endrés' manuscripts at the Vienna Archives.

Endrés, A.R. 1870. 'Notizbuch II', one of the Endrés' manuscripts at the Vienna Archives.

Endrés, A.R. 1871. Letter to Captain John M. Dow, September 27, 1872. John MelmothDow papers, \#2765. Division of Rare and Manuscript Collections, Cornell University Library. Endrés indicates that he had been under contract with Bateman and Reichenbach until that date, and he will work from now on for Veitch \& Sons.

Endrés, A.R. 1872. Letter to Captain John M. Dow, September 27, 1872. John MelmothDow papers, \#2765. Division of Rare and Manuscript Collections, Cornell University Library.

Endrés, A.R. 1872b. Letter to Captain John M. Dow, October 18, 1872. John MelmothDow papers, \#2765. Division of Rare and Manuscript Collections, Cornell University Library.

Endrés, A.R. 1874. Letter to Captain John M. Dow, January 12, 1874. John Melmoth Dow papers, \#2765. Division of Rare and Manuscript Collections, Cornell University Library. This is his last letter to Dow, where he indicates that he will leave for Europe in April of that year.

Flux, F. 1875. Letter to Hermann Tetens, February 15, 1875. Archives of the Vienna Natural History Museum.

Gutiérrez Braun, H. 1981. La ingeniería en Costa Rica 15021903. Editorial Tecnológica de Costa Rica, Cartago.

Herbitzheim (City of), 2008. Index of Birth Records \#70: Auguste Endrés, Nov. 27.

Hilje, L. 2008. Desde el ausente muelle, en Muelle. Tribuna Democrática, 13 de febrero. San José.

Kraenzlin, F.W. 1920. Orchidaceae Quaedam Americanae. Videnskabelige Meddelelser 71: 169-180.

Kraenzlin, F.W. 1921. Masdevalliae novae. Repert. Spec. Nov. Regni Veg. 17: 411-438.

Kraenzlin, F.W. 1922. Orchidaceae-Monandrae, Tribus 
Oncidiinae - Odontoglosseae. In: A.Engler, Das Pflanzenreich. IV,50: 1-344 Engelmann, Leipzig.

Kraenzlin, F.W. 1923. Orchidaceae-Monandrae-Pseudomonopodiales. In: A.Engler, Das Pflanzenreich IV.50: 1-66. Engelmann, Leipzig.

Kraenzlin, F.W. 1925. Monographie der Gattungen Masdevallia Ruiz et Pavon, Lothiania Kraenzl., Scaphosepalum Pfitzer, Cryptophorantus Barb, Rodr., Pseudoctomeria Kraenzl. Repert. Spec. Nov. Regni Veg. Beih. 34: 1-240.

Lankester, C. 1923. Letter to Oakes Ames, July 27, 1923. Lankester Botanical Garden, University of Costa Rica.

Luer, C. A. 1992. New species of Lepanthes Sw. (Orchidaceae). Lindleyana 7(2): 100-118.

Luer, C. A. 1995. New species of Lepanthes (Orchidaceae) from Costa Rica (with a biographical note on A. R. Endrés). Lindleyana 10(3): 133-175.

Luer, C. A. 1996. New species in the Pleurothallidinae (Orchidaceae). Lindleyana 11(2): 54-113.

Luer, C. A. 1999. Miscellaneous new species in the Pleurothallidinae. Orquideología 21(3): 318-340.

Manning, S. (in press). Discovering New World Orchids.

Missouri Botanical Garden, 1995-2008. Proyecto Manual de Plantas de Costa Rica: Gazetteer of Costa Rican Plant-Collecting Locales. At the web: http://www. mobot.org/MOBOT/Research/costaricagaz.shtml.

Molina, F. 1851. Bosquejo de la República de Costa Rica seguido de Apuntamientos para su Historia. S.W. Benedict, New York.

Natural History Museum in Vienna, 2010. Virtual Herbaria, digital images on web page. http://herbarium.univie. ac.at/database/search.php

Nicholson, G., 1886. Illustrated dictionary of gardening. Upcott Gill, London.

Ossenbach, C. 2003. Breve Historia de la Orquideología en Costa Rica. Editorial de la Universidad de Costa Rica, San José, Costa Rica.

Ossenbach, C. 2009. Orchids and Orchidology in Central America: 500 years of history. Lankesteriana 9(1-2): 1-268.

Paniagua, R.L. 1943. Apuntes Históricos y Crónicas de la Ciudad de San Ramón en su Centenario. Imprenta la Tribuna, San José, Costa Rica.

Pupulin, F., 2001. Contributions to a reassessment of Costa Rican Zygopetalinae (Orchidaceae). The genus Kefersteinia Rchb.f. Ann. Naturhist. Mus. Wien 103B: 525-555.

Pupulin, F. \& C. Ossenbach, 2005. Orchidology in Costa Rica. Pp. XI-XXX in: Pupulin, F. (ed.), Vanishing Beauty, Native Orchids of Costa Rica. Editorial de la Universidad de Costa Rica, San José, Costa Rica.

Reichenbach, H.G. 1870. New Garden Plants: Stelis endresii. Gard. Chron. 1870:1373-1374.
Reichenbach, H.G. 1871. New Garden Plants: Maxillaria reichenheimiana. Gard. Chron. 1871: 1678.

Reichenbach, H.G. 1872a. New Garden Plants: Batemania burtii. Gard. Chron. 1872: 1099.

Reichenbach, H.G. 1872b. New Garden Plants: Lockhartia amoena. Gard. Chron. 1872: 666-667.

Reichenbach, H.G. 1872c. Maxillaria nasalis. Saunders Refugium Botanicum 2(2): 103.

Reichenbach, H.G. 1872d. New Garden Plants: Pleurothallis lateritia. Gard. Chron. 1872: 731.

Reichenbach, H.G. 1872e. New Garden Plants: Zygopetalum lacteum. Gard. Chron. 1872: 1290.

Reichenbach, H.G. 1873. New Garden Plants: Brassia chlorops. Gard. Chron. 1873: 542.

Reichenbach, H.G. 1874. New Garden Plants: Lycaste xytriophora, Lycaste dowiana. Gard. Chron., n.s. 2: 194.

Reichenbach, H.G. 1874b. New Garden Plants: Ornithidium strumatum. Gard. Chron, n.s. 2: 772.

Reichenbach, H.G. 1875a. New garden plants: Epidendrum wallisii. Gard. Chron., n.s. 4: 66.

Reichenbach, H.G. 1875b. New garden plants: Masdevallia chimaera. Gard. Chron. 1875: 463.

Reichenbach, H.G. 1875c. New garden plants: Restrepia reichenbachiana. Gard. Chron. n.s.4: 356.

Reichenbach, H.G. 1875d. New garden plants: Masdevallia reichenbachiana. Gard. Chron. n.s.4: 257.

Reichenbach, H.G. 1876. New garden plants: Masdevallia triaristella. Gard. Chron. n.s.6: 226.

Reichenbach, H.G. 1877a. Orchidiographische Beiträge. Linnaea 41: 17-98.

Reichenbach, H.G. 1877b. New garden plants: Stanhopea pulla, Restrepia prorepens. Gard. Chron. n.s. 7: 810.

Reichenbach, H.G. 1881. Pleurothallis moschata. Xenia Orchidacea 3(2): 10-18, t. 217.

Reichenbach, H.G. 1883. New garden plants: Epidendrum Endresii Rchb. f. Gard. Chron. 19: 432.

Schlechter, F.R.R., 1921. Orchidaceae novae et criticae, Decas LXVIII. Repert. Spec. Nov. Regni Veg. 17: 1218.

Secretaría de Gobierno. 1924. Guanacaste - Libro conmemorativo del Centenario de la Incorporación del Partido de Nicoya a Costa Rica - 1824-1924. Imprenta María v. de Lines. San José, Costa Rica.

United States National Archives and Records Administration, 2008a. Superior Court, New York County, Vol. 167, record 206: petition for naturalization by Augustus R. Endres, Dec. 13, 1866.

United States National Archives and Records Administration, 2008b. US Passport Applications 1795-1925 (Publication M1372): passport application of Augustus R. Endres, Dec. 13, 1866.

United States National Archives and Records Administration, 
2008c. Records of the U.S. Customs Service, Microfilm 237, List 932: passenger list of the 'Abyssinia', arriving at New York from Liverpool, with 'A.R. Endries' [sic] and B. Roezl as passengers.

Valentini, F. J. J. 1869. Castilla de Oro -1502-1602 Estudios históricos sobre el descubrimiento: Conquista del Istmo de Darién, Veragua, Costa Rica, Nicaragua y Honduras. San José, Costa Rica. Unpublished manuscript.
Vargas, J.C. (ed.). 2008. Tropical Travel. The Representation of Central America in the Nineteenth Century. Facsimiles of illustrated texts (1854-1895). Editorial de la Universidad de Costa Rica, San José.

Veitch, J.H. 1906. Hortus Veitchii. Private edition, London. Wagner, M. \& C.R. von Scherzer. 1856. Die Republik Costa Rica in Central America. Arnold, Leipzig 
Appendix 1. Endrés' collecting localities.

\begin{tabular}{|c|c|c|}
\hline Locality name on Endrés label & Coordinates & Note \\
\hline \multicolumn{3}{|c|}{ Costa Rica } \\
\hline Acosta (Mina) & Unknown locality & Probably a gold mine - near San Ramón. \\
\hline Aguacaliente (Agua Caliente) & $1440 \mathrm{~m}, 9^{\circ} 51^{\prime} \mathrm{N} 83^{\circ} 56^{\circ} \mathrm{W}$ & Town in the E Valle Central, SW of Cartago \\
\hline Alajuela & $951 \mathrm{~m}, 10^{\circ} 01^{\prime} \mathrm{N} 84^{\circ} 13^{\prime} \mathrm{W}$ & City in the W Valle Central; capital of Prov. Alajuela \\
\hline Alumbre & $1550 \mathrm{~m} .9^{\circ} 48^{\prime} \mathrm{N} 84^{\circ} 02^{\prime} \mathrm{W}$ & $\begin{array}{l}\text { Village on the slope of the Cordillera de Talamanca, } \\
\text { SW of Cartago }\end{array}$ \\
\hline Angostura & $543 \mathrm{~m}, 9^{\circ} 53^{\prime} \mathrm{N} 83^{\circ} 40^{\prime} \mathrm{W}$ & Site to the SE of Turrialba \\
\hline Arenal [Volcano] & $1633 \mathrm{~m}, 10^{\circ} 28^{\prime} \mathrm{N} 84^{\circ} 42^{\prime} \mathrm{W}$ & $\begin{array}{l}\text { Isolated peak near the southern end of the Cordillera de } \\
\text { Guanacaste; most active volcano in Costa Rica. At } \\
\text { Endrés' time it was not known that it was a volcano and } \\
\text { was called 'Cerro de los Guatusos', which is the name } \\
\text { used by Endrés on his specimens }\end{array}$ \\
\hline Arenilla & $1388 \mathrm{~m}, 9^{\circ} 52^{\prime} \mathrm{N} 83^{\circ} 48^{\prime} \mathrm{W}$ & $\begin{array}{l}\text { Old name for Guadalupe. Suburb of Cartago, to the SW } \\
\text { of the town }\end{array}$ \\
\hline Atenas & $696 \mathrm{~m}, 9^{\circ} 58^{\prime} \mathrm{N} 84^{\circ} 23^{\prime} \mathrm{W}$ & Town in the W Valle Central; railroad station \\
\hline Atirro & $597 \mathrm{~m}, 9^{\circ} 50^{\prime} \mathrm{N} 83^{\circ} 40^{\prime} \mathrm{W}$ & Village to the SSE of Turrialba. \\
\hline Atlantic (sultry lowlands of the) & $\begin{array}{l}\text { The region between Siquirres } \\
\text { and the coast }\end{array}$ & $\begin{array}{l}\text { We assume that Endrés collected along the proposed } \\
\text { railroad to Limón. As a matter of fact, he intended to } \\
\text { explore Talamanca (in May 1872) but in his letter to } \\
\text { Capt. Dow of Oct. 18, } 1872 \text { he writes: "I was dissuaded } \\
\text { before I reached Limón" }\end{array}$ \\
\hline Azul, Quebrada & $800 \mathrm{~m}, 9^{\circ} 47^{\prime} \mathrm{N} 83^{\circ} 44^{\prime} \mathrm{W}$ & $\begin{array}{l}\text { Creek in the N Cordillera de Talamanca; a tributary of } \\
\text { the Río Pejibaye. Also Finca Azul, at the confluency of } \\
\text { the Quebrada with the Río Pejibaye }\end{array}$ \\
\hline $\begin{array}{l}\text { (La) Balsa de Atenas (de Río } \\
\text { Grande; de Tárcoles) (spelled } \\
\text { by Endrés 'Balza') }\end{array}$ & $425 \mathrm{~m}, 9^{\circ} 57^{\prime} \mathrm{N} 84^{\circ} 23^{\prime} \mathrm{W}$ & Railroad station in W Valle Central, S of Atenas \\
\hline Barranca (1) & $27 \mathrm{~m}, 9^{\circ} 59^{\prime} 41^{\prime \prime} \mathrm{N} 84^{\circ} 43^{\prime} 29^{\prime \prime} \mathrm{W}$ & Village 7 miles to the $\mathrm{E}$ of Puntarenas \\
\hline Barranca (2) & $614 \mathrm{~m}, 10^{\circ} 05^{\prime} \mathrm{N} 84^{\circ} 32^{\prime} \mathrm{W}$ & Hamlet 4 miles West of San Ramón \\
\hline Barva (or, Barba) & $1177 \mathrm{~m}, 10^{\circ} 02^{\prime} \mathrm{N} 84^{\circ} 08^{\prime} \mathrm{W}$ & NW suburb of Heredia \\
\hline $\begin{array}{l}\text { Barva volcano (spelled by } \\
\text { Endrés 'Barba') }\end{array}$ & $2906 \mathrm{~m}, 10^{\circ} 08^{\prime} \mathrm{N} 84^{\circ} 06^{\prime} \mathrm{W}$ & $\begin{array}{l}\text { In the Central Mountain Range, } 15 \text { miles to the } \mathrm{N} \text { of } \\
\text { San José }\end{array}$ \\
\hline Birrís (spelled by Endrés 'Virrís') & $1253 \mathrm{~m}, 9^{\circ} 53^{\prime} \mathrm{N} 83^{\circ} 47^{\prime} \mathrm{W}$ & Village along the Río Birrís, just NE of Cervantes \\
\hline Boquerón & $1793 \mathrm{~m}, 9^{\circ} 90^{\prime} \mathrm{N} 83^{\circ} 50^{\prime} \mathrm{W}$ & $\begin{array}{l}\text { Village N of Cartago, about } 1 \text { mile E of Cot, on the } \\
\text { slopes of Irazú volcano }\end{array}$ \\
\hline Bóveda & $726 \mathrm{~m}, 9^{\circ} 54^{\prime} \mathrm{N} 83^{\circ} 39^{\prime} \mathrm{W}$ & $\begin{array}{l}\text { Village to the } \mathrm{W} \text { of Turrialba, on the road to Siquirres, } \\
\text { between Eslabón and Pavones }\end{array}$ \\
\hline Buena Vista, Cerro and Páramo & $3491 \mathrm{~m}, 9^{\circ} 35^{\prime} \mathrm{N} 83^{\circ} 45^{\prime} \mathrm{W}$ & $\begin{array}{l}\text { Mountain and highland plain in the Cordillera of } \\
\text { Talamanca }\end{array}$ \\
\hline Buena Vista (de San Carlos) & $850 \mathrm{~m}, 10^{\circ} 17^{\prime} \mathrm{N} 84^{\circ} 28^{\prime} \mathrm{W}$ & $\begin{array}{l}\text { Town on the westernmost slope of the Cordillera } \\
\text { Central, SW of Ciudad Quesada }\end{array}$ \\
\hline
\end{tabular}




\begin{tabular}{|c|c|c|}
\hline Locality name on Endrés label & Coordinates & Note \\
\hline Cacao, Río & $800 \mathrm{~m}, 9^{\circ} 59^{\prime} \mathrm{N} 84^{\circ} 26^{\prime} \mathrm{W}$ & $\begin{array}{l}\text { River draining the E slope of the Montes del Aguacate, } \\
\text { flowing just N of Atenas; a tributary of the Río Grande } \\
\text { de Tárcoles }\end{array}$ \\
\hline (La) Calera (de San Ramón) & $1100 \mathrm{~m}, 10^{\circ} 01^{\prime} \mathrm{N} 84^{\circ} 29^{\prime} \mathrm{W}$ & Site on the S slope of the Montes del Aguacate \\
\hline Calvario on the cliffs & & $\begin{array}{l}\text { Road to Limón (?). A Calvary (stations of the Cross), } \\
\text { somewhere along the Limón road, then under } \\
\text { construction. Probably a collecting locality during his } \\
\text { intended trip to Talamanca, in May } 1872\end{array}$ \\
\hline Camino de Boruca & & $\begin{array}{l}\text { The road to the lowlands of Boruca, after crossing the } \\
\text { Cerro Buena Vista }\end{array}$ \\
\hline Candelaria & $1010 \mathrm{~m}, 10^{\circ} 02^{\prime} \mathrm{N} 84^{\circ} 25^{\prime} \mathrm{W}$ & $\begin{array}{l}\text { Village about } 2 \text { miles } \mathrm{S} \text { of Palmares, on the road to } \\
\text { Atenas }\end{array}$ \\
\hline Candelaria (Cerros de) & $\begin{array}{l}1000-2100 \mathrm{~m}, 9^{\circ} 43-50^{\prime} \mathrm{N} \\
84^{\circ} 00-07^{\prime} \mathrm{W}\end{array}$ & $\begin{array}{l}\text { A mountainous region, part of the N Cordillera de } \\
\text { Talamanca, comprising the drainage basins of the Ríos } \\
\text { Tarrazú, Alumbre, and Santa Elena }\end{array}$ \\
\hline Candelaria, Río (Grande de) & $1100 \mathrm{~m}, 9^{\circ} 47^{\prime} \mathrm{N} 84^{\circ} 06^{\prime} \mathrm{W}$ & $\begin{array}{l}\text { Major river draining the S slope of the Cerros de } \\
\text { Escazú, portions of the N Cordillera de Talamanca, etc., } \\
\text { formed by the confluence of the Río Alumbre and the } \\
\text { Río Tarrazú; an affluent (with the Río Pirrís) of the Río } \\
\text { Parrita }\end{array}$ \\
\hline Carmen, Llanos del & Plain to the SW of Alajuela & $\begin{array}{l}\text { Site between Turrúcares and Alajuela (occupied today } \\
\text { in great part by the industrial zone of El Coyol) }\end{array}$ \\
\hline $\begin{array}{l}\text { Carpintera, Cerro(s) de la } \\
\text { (spelled by Endrés 'Carpintaria') }\end{array}$ & $1870 \mathrm{~m}, 9^{\circ} 53^{\prime} \mathrm{N} 83^{\circ} 49^{\prime} \mathrm{W}$ & $\begin{array}{l}\text { Serranía at the S margin of the Valle Central, } \\
\text { connecting the Cordillera de Talamanca and the } \\
\text { Cordillera Central }\end{array}$ \\
\hline Carranza's, Camino de los & & San Ramón. Path near Potrerillos \\
\hline Cartago & $1426 \mathrm{~m}, 9^{\circ} 52^{\prime} \mathrm{N} 83^{\circ} 55^{\prime} \mathrm{W}$ & City in the E Valle Central; capital of Prov. Cartago \\
\hline Cataratas de San Ramón & & $\begin{array}{l}\text { Village in the district of Los Ángeles de San Ramón, } \\
\text { near the confluence of the rivers Balsa and Cataratas } \\
\text { (not shown on modern maps) }\end{array}$ \\
\hline Cervantes & $1441 \mathrm{~m}, 83^{\circ} 49^{\prime} \mathrm{W}, 9^{\circ} 53^{\prime} \mathrm{N}$ & Village E of Cartago, on the road to Turrialba \\
\hline Chacarita & $4 \mathrm{~m}, 84^{\circ} 45^{\prime} \mathrm{W} 10^{\circ} 00^{\prime} \mathrm{N}$ & Hamlet 3 miles $\mathrm{E}$ of Puntarenas \\
\hline $\begin{array}{l}\text { Chiz (as "Chis") } \\
\text { the Río Chiz }\end{array}$ & $835 \mathrm{~m}, 9^{\circ} 52^{\prime} \mathrm{N} 83^{\circ} 43^{\prime} \mathrm{W}$ & Small hamlet to the SE of Juan Viñas, on the banks of \\
\hline Chiz, Río (as " Chis & $829 \mathrm{~m}, 9^{\circ} 52^{\prime} \mathrm{N} 83^{\circ} 43^{\prime} \mathrm{W}$ & A tributary of the Río Reventazón \\
\hline Coliblanco & $2350 \mathrm{~m} .9^{\circ} 57^{\prime} \mathrm{N} 83^{\circ} 48^{\prime} \mathrm{W}$ & Town on the SE slope of Volcán Irazú \\
\hline Colorado (Heights of) & $1000 \mathrm{~m}, 83^{\circ} 42^{\prime} \mathrm{W} 9^{\circ} 55^{\prime} \mathrm{N}$ & Hamlet WNW of Turrialba \\
\hline Copalchí (spelled ‘Colpachí') & $1854 \mathrm{~m}, 9^{\circ} 48^{\prime} \mathrm{N} 84^{\circ} 02^{\prime} \mathrm{W}$ & Village SW of Cartago, on the road to Frailes \\
\hline Corralillo & $1665 \mathrm{~m} .9^{\circ} 48^{\prime} \mathrm{N} 84^{\circ} 01^{\prime} \mathrm{W}$ & Town $15 \mathrm{~km} \mathrm{SW}$ of Cartago \\
\hline Cot & $1820 \mathrm{~m}, 9^{\circ} 54^{\prime} \mathrm{N} 83^{\circ} 452^{\prime} \mathrm{W}$ & $\begin{array}{l}\text { Village to the NE of Cartago, on the road to Irazú } \\
\text { volcano }\end{array}$ \\
\hline Desengaño, Paso del (or Alto del) & 1899 m, $1010^{\prime} \mathrm{N} 84$ 10’W & $\begin{array}{l}\text { Mountain pass between the Poás and Barva volcanoes. } \\
\text { Historically important as the route to the lowlands of } \\
\text { Sarapiquí }\end{array}$ \\
\hline
\end{tabular}




\begin{tabular}{|c|c|c|}
\hline Locality name on Endrés label & Coordinates & Note \\
\hline Dota, Boca de & 1404 m. $9^{\circ} 40^{\prime} \mathrm{N} 84^{\circ} 01^{\prime} \mathrm{W}$ & $\begin{array}{l}\text { Site located to the South of where the village of San } \\
\text { Marcos de Tarrazú was later founded. Today known as } \\
\text { Santa Marta de San Lorenzo de Tarrazú }\end{array}$ \\
\hline $\begin{array}{l}\text { Dragón, Cerro (better known } \\
\text { as Cerro Caraigres) }\end{array}$ & $2508 \mathrm{~m}, 9^{\circ} 43^{\prime} \mathrm{N} 84^{\circ} 08^{\prime} \mathrm{W}$ & $\begin{array}{l}\text { Geologically complex and intriguing subsidiary peak in } \\
\text { the } \mathrm{N} \text { part of the Cordillera de Talamanca; also known } \\
\text { as Cerro de Los Cuarteles }\end{array}$ \\
\hline Escazu's, Camino de los & & San Ramón. Path near Potrerillos \\
\hline Esparza & $168 \mathrm{~m}, 1000^{\prime} \mathrm{N} 84$ 40’ W & Town on the old road to Puntarenas \\
\hline Fajardo & $1000 \mathrm{~m}, 9^{\circ} 51^{\prime} \mathrm{N} 83^{\circ} 43^{\prime} \mathrm{W}$ & $\begin{array}{l}\text { Site north of the Cachí dam on the Reventazón river. } \\
\text { Narrow gorge also known as 'Puente [bridge] de } \\
\text { Fajardo' or 'Rocas [rocks] of Fajardo' }\end{array}$ \\
\hline $\begin{array}{l}\text { Felipe Diaz (La Cañada } \\
\text { de Felipe Días) }\end{array}$ & $9^{\circ} 58^{\prime} \mathrm{N} 83^{\circ} 54^{\prime} \mathrm{W}$ & $\begin{array}{l}\text { Today simply "La Cañada". Village to the SW of Irazú } \\
\text { volcano, } 1.5 \text { miles NE ofLlano Grande. Named after a } \\
\text { Spanish conqueror who received land grants on the } \\
\text { slopes of Irazú volcano back in } 1569\end{array}$ \\
\hline Frailes, Los & $1596 \mathrm{~m}, 9^{\circ} 45^{\prime} \mathrm{N} 84^{\circ} 40^{\prime} \mathrm{W}$ & $\begin{array}{l}\text { Village on the road from Desamparados to Tarrazú and } \\
\text { Dota. Frailes, Spanish for friars, was a community of } \\
\text { friars from the order of St. Francis, established in the } \\
\text { area in the last quarter of the 18th century }\end{array}$ \\
\hline Garita, La & $\begin{array}{l}675 \mathrm{~m}, 959^{\prime} 30 ” \mathrm{~N} \\
8419^{\prime} 00 ” \mathrm{~W}\end{array}$ & $\begin{array}{l}\text { Village } 2.5 \text { miles } \mathrm{N} \text { of Turrúcares, on the road from } \\
\text { Alajuela to Atenas }\end{array}$ \\
\hline Granados, Savanna de los & $2200 \mathrm{~m}, 9^{\circ} 38^{\prime} \mathrm{N} 83^{\circ} 55^{\prime} \mathrm{W}$ & $\begin{array}{l}\text { House and pastures of Patricio Granados, in Copey de } \\
\text { Dota. Town in the Cordillera de Talamanca, E of Santa } \\
\text { María de Dota }\end{array}$ \\
\hline Grande, Cerro, Cartago & $2539 \mathrm{~m}, 1000^{\prime} \mathrm{N} 8350^{\prime} \mathrm{W}$ & Mountain southwest of Turrialba volcano \\
\hline Grande de Tárcoles, Río & & $\begin{array}{l}\text { Formed by the confluence of the rivers Grande de San } \\
\text { Ramón and Virilla, near Atenas }\end{array}$ \\
\hline Grecia & $1015 \mathrm{~m}, 10^{\circ} 04^{\prime} \mathrm{N} 84^{\circ} 18^{\prime} \mathrm{W}$ & $\begin{array}{l}\text { Town in the W Valle Central, between Sarchí (Norte) } \\
\text { and San Pedro de Poás }\end{array}$ \\
\hline Guatuso & $1390 \mathrm{~m}, 9^{\circ} 49^{\prime} \mathrm{N} 83^{\circ} 57^{\circ} \mathrm{W}$ & $\begin{array}{l}\text { Town at the S edge of the E Valle Central, SW of } \\
\text { Cartago }\end{array}$ \\
\hline $\begin{array}{l}\text { Guayabo (1) (spelled by } \\
\text { Endrés often 'Guayavo') }\end{array}$ & $800 \mathrm{~m}, 9^{\circ} 58^{\prime} \mathrm{N} 83^{\circ} 38^{\prime} \mathrm{W}$ & $\begin{array}{l}\text { Turrialba. Site NE of Turrialba; small hamlet at the } \\
\text { the confluence of the Guayabo and Reventazón Rivers }\end{array}$ \\
\hline $\begin{array}{l}\text { Guayabo (2), Hacienda de (Finca) } \\
\text { (spelled often 'Guayavo') }\end{array}$ & $900 \mathrm{~m}, 9^{\circ} 58^{\prime} \mathrm{N} 83^{\circ} 40^{\prime} \mathrm{W}$ & $\begin{array}{l}\text { Site N of Turrialba; once owned by Mme. Amparo de } \\
\text { Zeledón, noted patron of orchid collectors. The } \\
\text { Guayabo, National monument is nearby at } 1050 \mathrm{~m} \text {, } \\
9^{\circ} 58^{\prime} \mathrm{N} 83^{\circ} 41^{\prime} \mathrm{W} \text {. Archeological site on the E slope of } \\
\text { Volcán Turrialba. }\end{array}$ \\
\hline "Hacienda de don Pío Murillo & & $\begin{array}{l}\text { Close to the crater of the Barva volcano. A farm } \\
\text { from Spain in } 1821 \text {. Murillo had been one of the first to } \\
\text { explore the routes to the region of Sarapiquí in the } \\
\text { years of } 1832 \text { and } 1833\end{array}$ \\
\hline "Hacienda la Francia" & 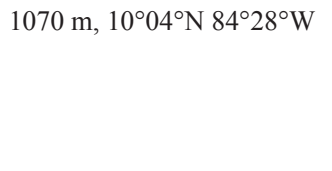 & $\begin{array}{l}\text { Coffee farm property of the Frenchman Victor } \\
\text { Dujardin, in the district of San Rafael de San Ramón. } \\
\text { The farm was located in what is today the center of the } \\
\text { village and the street on the north side of the church is } \\
\text { still called "La Francia" }\end{array}$ \\
\hline
\end{tabular}




\begin{tabular}{|c|c|c|}
\hline Locality name on Endrés label & Coordinates & Note \\
\hline Honda, Quebrada (1) & $1014 \mathrm{~m}, 9^{\circ} 53^{\prime} \mathrm{N} 83^{\circ} 47^{\prime} \mathrm{W}$ & $\begin{array}{l}\text { Creek draining the SE foothills of Volcán Irazú; a } \\
\text { tributary of the Río Reventazón. N.B.: "Quebrada } \\
\text { Honda" is one of the most common place names } \\
\text { in Costa Rica. This is perhaps the most important one } \\
\text { botanically, but there are others, and some cannot be } \\
\text { localized with certainty }\end{array}$ \\
\hline Honda, Quebrada (2) & $900 \mathrm{~m}, 9^{\circ} 58^{\prime} \mathrm{N} 84^{\circ} 28^{\prime} \mathrm{W}$ & $\begin{array}{l}\text { Creek with its source near Zapote, some } 3.5 \text { miles } \\
\text { South of Santiago de San Ramón, flowing into the Río } \\
\text { Machuca. Also a site with the same name about } 1.3 \\
\text { miles North of Desmonte, probably an abandoned mine }\end{array}$ \\
\hline Iglesias, Mina & & Site (mine) along or near the Río Barranca, Puntarenas \\
\hline Irazú volcano & $3432 \mathrm{~m}, 9^{\circ} 49^{\prime} \mathrm{N} 83^{\circ} 50^{\prime} \mathrm{W}$ & $\begin{array}{l}\text { In the Central Mountain Range, } 20 \text { miles Northeast of } \\
\text { Cartago }\end{array}$ \\
\hline Itiquís (Cabecera del río) & $1295 \mathrm{~m}, 10^{\circ} 04^{\prime} \mathrm{N} 84^{\circ} 11^{\prime} \mathrm{W}$ & $\begin{array}{l}\text { Headwaters of Itiquís River on the southwestern slope } \\
\text { of Barva volcano }\end{array}$ \\
\hline Jardín (El) & $2230 \mathrm{~m}, 9^{\circ} 43^{\prime} \mathrm{N} 83^{\circ} 58^{\prime} \mathrm{W}$ & $\begin{array}{l}\text { Town in the Cordillera de Talamanca SW of El } \\
\text { Empalme, along the road to Santa María de Dota }\end{array}$ \\
\hline Jesús María, Río & $100-200 \mathrm{~m}, 9^{\circ} 58^{\prime} \mathrm{N} 84^{\circ} 37^{\prime} \mathrm{W}$ & $\begin{array}{l}\text { River draining the Montes del Aguacate, flowing to the } \\
\text { sea at Tivives }\end{array}$ \\
\hline Jilguero (spelled 'Cilguero') & $779 \mathrm{~m}, 10^{\circ} 25^{\prime} \mathrm{N} 84^{\circ} 43^{\prime} \mathrm{W}$ & $\begin{array}{l}\text { Hamlet on the SW slope of Cerro Chato, about } 3 \text { miles } \\
\text { S of Arenal volcano }\end{array}$ \\
\hline Jorco, Río & $\begin{array}{l}230-600+\mathrm{m}, 9^{\circ} 47-48^{\prime} \mathrm{N} \\
84^{\circ} 15-19^{\prime} \mathrm{W}\end{array}$ & A tributary of the Río Grande de Candelaria \\
\hline Juan Viñas, Río & $9^{\circ} 56^{\prime} \mathrm{N} 83^{\circ} 47^{\prime} \mathrm{W}$ (headwaters) & $\begin{array}{l}\text { Today known as Río Maravilla. Its headwaters are just } \\
\text { SE of Santa Teresa, on the SE slope of Volcán Irazú, } \\
\text { NE of Capellades. A tributary of the Chiz River, who is } \\
\text { a tributary of the Reventazón }\end{array}$ \\
\hline $\begin{array}{l}\text { Laguna de Zarcero } \\
\qquad \text { (or de Alfaro Ruiz) }\end{array}$ & $1850 \mathrm{~m}, 10^{\circ} 13^{\prime} \mathrm{N} 84^{\circ} 20^{\prime} \mathrm{W}$ & $\begin{array}{l}\text { Town on the W slope of the Cordillera Central, just NW } \\
\text { of Zarcero along the road to Ciudad Quesada }\end{array}$ \\
\hline Legua (Cuesta de la) & & San Ramón de Alajuela, camino a San Carlos (?) \\
\hline Legua de Desamparados & $1649 \mathrm{~m} .9^{\circ} 45^{\prime} \mathrm{N} 84^{\circ} 08^{\prime} \mathrm{W}$ & $\begin{array}{l}\text { Today known as Legua de Aserrí. Village to the N. of } \\
\text { Aserrí }\end{array}$ \\
\hline \multicolumn{3}{|l|}{ Lluvioso, Cerro (?) } \\
\hline Macacona (de Esparza) & $243 \mathrm{~m}, 10^{\circ} 00^{\prime} \mathrm{N} 84^{\circ} 39^{\prime} \mathrm{W}$ & $\begin{array}{l}\text { Town along the Carretera Interamericana, just NE of } \\
\text { Esparza }\end{array}$ \\
\hline (La) Matina & $11 \mathrm{~m}, 10^{\circ} 05^{\prime} \mathrm{N} 83^{\circ} 18^{\prime} \mathrm{W}$ & $\begin{array}{l}\text { Railroad station on the Llanura de Santa Clara, near the } \\
\text { upper Río Matina }\end{array}$ \\
\hline (La) Mina, Cerro & $400 \mathrm{~m} .10^{\circ} 03^{\prime} \mathrm{N} 84^{\circ} 40^{\prime} \mathrm{W}$ & Hill about $9 \mathrm{~km} \mathrm{SE}$ of Miramar \\
\hline Mina San Gerardo & $500 \mathrm{~m}, 10^{\circ} 03^{\prime} \mathrm{N} 84^{\circ} 35^{\prime} \mathrm{W}$ & $\begin{array}{l}\text { Abandoned gold mine in the mine district near the } \\
\text { confluence of the rivers Jesús and Barranca }\end{array}$ \\
\hline Monte Redondo & $1140 \mathrm{~m}, 9^{\circ} 48^{\prime} \mathrm{N} 84^{\circ} 08^{\prime} \mathrm{W}$ & Town in the valley of the Río Grande de Candelaria \\
\hline Naranjo (de Juan Viñas) & $1242 \mathrm{~m}, 9^{\circ} 53^{\prime} \mathrm{N} 83^{\circ} 46^{\prime} \mathrm{W}$ & Town just W of Juan Viñas \\
\hline Navarro & $1100 \mathrm{~m}, 9^{\circ} 48^{\prime} \mathrm{N} 83^{\circ} 53^{\prime} \mathrm{W}$ & $\begin{array}{l}\text { Town in the N Cordillera de Talamanca, in the valley of } \\
\text { the Río Agua Caliente, near its confluence with the Río } \\
\text { Navarro }\end{array}$ \\
\hline
\end{tabular}




\begin{tabular}{|c|c|c|}
\hline Locality name on Endrés label & Coordinates & Note \\
\hline Ochomogo & $1500 \mathrm{~m}, 9^{\circ} 53^{\prime} \mathrm{N} 83^{\circ} 57^{\prime} \mathrm{W}$ & $\begin{array}{l}\text { Mountain pass along the main road between San José } \\
\text { and Cartago, dividing the central highland of Costa } \\
\text { Rica into the Eastern and Western Valley }\end{array}$ \\
\hline Ojo de Agua (1) & $840 \mathrm{~m}, 9^{\circ} 58^{\prime} \mathrm{N} 84^{\circ} 13^{\prime} \mathrm{W}$ & Railroad station in the Valle Central, S of Alajuela \\
\hline Ojo de Agua (2) & $2980 \mathrm{~m}, 9^{\circ} 37^{\prime} \mathrm{N} 83^{\circ} 49^{\prime} \mathrm{W}$ & Site near Cerro de las Vueltas, Cartago \\
\hline Orosi & $1051 \mathrm{~m}, 9^{\circ} 48^{\prime} \mathrm{N} 83^{\circ} 52^{\prime} \mathrm{W}$ & $\begin{array}{l}\text { Town in the N Cordillera de Talamanca, in the valley of } \\
\text { the Río Grande de Orosi }\end{array}$ \\
\hline Pacaca & $799 \mathrm{~m}, 9^{\circ} 55^{\prime} \mathrm{N} 84^{\circ} 15^{\prime} \mathrm{W}$ & $\begin{array}{l}\text { Former name for Colón (Ciudad; Villa), town in the W } \\
\text { Valle Central }\end{array}$ \\
\hline Pacuare, Río & $\begin{array}{l}70 \mathrm{~m}, 10^{\circ} 05^{\prime} 41^{\prime \prime} \mathrm{N} 83^{\circ} 29^{\prime} 18^{\prime \prime} \mathrm{W} \\
\text { (where Siquirres-Limón highway } \\
\text { crosses river); } 10^{\circ} 05^{\prime} 26^{\prime} \mathrm{N} \\
83^{\circ} 29^{\prime} 20^{\prime \prime} \mathrm{W} \text { (at Northern } \\
\text { Railroad crossing) }\end{array}$ & $\begin{array}{l}\text { River draining the N Cordillera de Talamanca, flowing } \\
\text { to the sea between Parismina and Puerto Limón }\end{array}$ \\
\hline Paires, Río (as ‘Payres’) & & $\begin{array}{l}\text { River to the W of Esparza. A tributary of Río Jesús } \\
\text { María }\end{array}$ \\
\hline Palmares, Cerros de los & $1353 \mathrm{~m}, 10^{\circ} 05^{\prime} \mathrm{N} 84^{\circ} 25^{\prime} \mathrm{W}$ & $\begin{array}{l}\text { 19th century denomination for the hills to the East of } \\
\text { San Ramón and Palmares, whith the Cerro del Espíritu } \\
\text { Santo as one of its main elevations }\end{array}$ \\
\hline Palmira, Cerro & $2184 \mathrm{~m}, 10^{\circ} 12^{\prime} \mathrm{N} 84^{\circ} 21^{\prime} \mathrm{W}$ & $\begin{array}{l}\text { Promontory in the W portion of the Cordillera Central, } \\
\text { SE of Palmira de Alfaro Ruiz; an extinct volcano }\end{array}$ \\
\hline Palo Blanco & $1700 \mathrm{~m}, 9^{\circ} 49^{\prime} \mathrm{N} 83^{\circ} 58^{\prime} \mathrm{W}$ & Site on the slope above San Isidro de Cartago \\
\hline Paquita, Río & $80 \mathrm{~m}, 9^{\circ} 31^{\prime} \mathrm{N} 84^{\circ} 06^{\prime} \mathrm{W}$ & $\begin{array}{l}\text { River draining the Cordillera de Talamanca, flowing to } \\
\text { the sea (Boca Damas) just N of Puerto Quepos }\end{array}$ \\
\hline Paraíso & $1350 \mathrm{~m}, 9^{\circ} 50^{\prime} \mathrm{N} 83^{\circ} 51^{\prime} \mathrm{W}$ & Town W of Cartago, on the road to Turrialba \\
\hline Parrita, Río & & $\begin{array}{l}\text { Major river draining the Cordillera de Talamanca, } \\
\text { formed by the confluence of the Río Grande de } \\
\text { Candelaria and the Río Pirrís }\end{array}$ \\
\hline Parrita Grande, Río & & $\begin{array}{l}\text { Old name for the upper part of the Río Pirrís, in the } \\
\text { region of S. Marcos de Tarrazú and Sta María de Dota }\end{array}$ \\
\hline Pascón & $1742 \mathrm{~m}, 9^{\circ} 55^{\prime} \mathrm{N} 83^{\circ} 48^{\prime} \mathrm{W}$ & Hamlet 1.3 miles SW of Pacayas, NE of Cartago \\
\hline Patarrá & $1170 \mathrm{~m}, 9^{\circ} 53^{\prime} \mathrm{N} 84^{\circ} 02^{\prime} \mathrm{W}$ & SE suburb of San José \\
\hline (La) Paz de San Ramón & $1110 \mathrm{~m}, 10^{\circ} 08^{\prime} \mathrm{N} 84^{\circ} 32^{\prime} \mathrm{W}$ & Village in the Cordillera de Tilarán, NW of San Ramón \\
\hline Peje, Río & $100 \mathrm{~m}, 10^{\circ} 24^{\prime} \mathrm{N} 84^{\circ} 30^{\prime} \mathrm{W}$ & $\begin{array}{l}\text { River draining the northernwesternmost slopes of the } \\
\text { Cordillera Central; a tributary of the Río San Carlos }\end{array}$ \\
\hline Pejibaye (as "Pejivalle") & $650 \mathrm{~m}, 9^{\circ} 48^{\prime} \mathrm{N} 83^{\circ} 43^{\prime} \mathrm{W}$ & $\begin{array}{l}\text { Town in the N Cordillera de Talamanca, along the Río } \\
\text { Pejibaye }\end{array}$ \\
\hline Pejibaye, Río & $750 \mathrm{~m}, 9^{\circ} 47^{\prime} \mathrm{N} 83^{\circ} 43^{\prime} \mathrm{W}$ & $\begin{array}{l}\text { River draining the } \mathrm{N} \text { part of the Cordillera de } \\
\text { Talamanca; a tributary of the Río Reventazón }\end{array}$ \\
\hline Pelón, Cerro & $926 \mathrm{~m}, 9^{\circ} 43^{\prime} \mathrm{N} 84^{\circ} 24^{\prime} \mathrm{W}$ & Hill in the Puriscal region, $\mathrm{S}$ of Salitrales \\
\hline Picagres & $600 \mathrm{~m}, 9^{\circ} 54^{\prime} \mathrm{N} 84^{\circ} 21^{\prime} \mathrm{W}$ & $\begin{array}{l}\text { Village about } 5 \text { miles NW of Puriscal, on the SE slope } \\
\text { of the Río Grande de Tárcoles }\end{array}$ \\
\hline Pico Blanco, Cerro & $2428 \mathrm{~m}, 9^{\circ} 87^{\prime} \mathrm{N} 84^{\circ} 14^{\prime} \mathrm{W}$ & $\begin{array}{l}\text { Second highest mountain of the Cerros de Escazú, SW } \\
\text { of San José }\end{array}$ \\
\hline
\end{tabular}




\begin{tabular}{|c|c|c|}
\hline Locality name on Endrés label & Coordinates & Note \\
\hline Piedras (Río) & & A tributary of the Río Barranca, NW from San Ramón \\
\hline Picada de Pedro Calderón & & $\begin{array}{l}\text { Trail established in } 1866 \text { which led from Santa María } \\
\text { de Dota over Copey and the Páramo de Vueltas to the } \\
\text { Valley of El General. Pedro Calderón Ureña started } \\
\text {-together with his son-in-law Juan López Alfaro- from } \\
\text { the village of Copey de Dota, and used the house of } \\
\text { Patricio Granados as his base camp (see other collections } \\
\text { by Endrés referring to the "savanna de los Granados") }\end{array}$ \\
\hline Pito, Cerro El & $1460 \mathrm{~m}, 9^{\circ} 35^{\prime} \mathrm{N} 84^{\circ} 04^{\prime} \mathrm{W}$ & $\begin{array}{l}\text { Promontory SW of San Marcos de Tarrazú; sometimes } \\
\text { given as "Alto de La Pita" }\end{array}$ \\
\hline Pizirres & $2000 \mathrm{~m}, 9^{\circ} 48^{\prime} \mathrm{N} 84^{\circ} 01^{\prime} \mathrm{W}$ & $\begin{array}{l}\text { Today known as "Calle Pizirres", site in the district of } \\
\text { Patio de Agua (Tejar) }\end{array}$ \\
\hline Poás, Volcán (Massif du) & $2708 \mathrm{~m}, 10^{\circ} 11^{\prime} \mathrm{N} 84^{\circ} 14^{\prime} \mathrm{W}$ & $\begin{array}{l}\text { Major, active volcano in the Cordillera Central; } \\
\text { formerly known as "Volcán de Los Votos" (or "Botos") }\end{array}$ \\
\hline Potrerillos, San Ramón & $\begin{array}{l}\text { ca. } 1000 \mathrm{~m}, 10^{\circ} 07^{\prime} 00^{\prime \prime} \mathrm{N} \\
84^{\circ} 32^{\prime} 12^{\prime \prime} \mathrm{W}\end{array}$ & small village near Piedades Norte \\
\hline Potrero Cerrado & $2196 \mathrm{~m}, 9^{\circ} 55^{\prime} \mathrm{N} 83^{\circ} 52^{\prime} \mathrm{W}$ & Village on the road from Cartago to the Irazú volcano \\
\hline Pozón (Cerros del) & & San Ramón (?) \\
\hline Quebrada Verde & $1020 \mathrm{~m}, 10^{\circ} 12^{\prime} \mathrm{N} 84^{\circ} 30^{\prime} \mathrm{W}$ & $\begin{array}{l}\text { Creek in the Cordillera de Tilarán, just NW of La Balsa; } \\
\text { a tributary of the Río Balsa }\end{array}$ \\
\hline Quemado, Cerro & & Near Santa María de Dota (?) \\
\hline Reventazón (Río; River) & $\begin{array}{l}80 \mathrm{~m}, 10^{\circ} 06^{\prime} 45^{\prime \prime} \mathrm{N} 83^{\circ} 31^{\prime} 36^{\prime \prime} \mathrm{W} \\
\text { (measured at benchmark } 80, \\
\text { bridge just west of Siquirres) }\end{array}$ & $\begin{array}{l}\text { Major river draining the S Cordillera Central, E Valle } \\
\text { Central, and N Cordillera de Talamanca, formed by the } \\
\text { confluence of the Río Agua Caliente and the Río } \\
\text { Grande de Orosi; a tributary of the lower Río } \\
\text { Parismina. The upper portions of the river (above ca. } \\
330 \mathrm{~m} \text { ) are in Prov. Cartago. According to local usage } \\
\text { (but not maps), "Río Reventazón" includes the Río } \\
\text { Grande de Orosi }\end{array}$ \\
\hline Río Grande de San Ramón & & $\begin{array}{l}\text { River with its headwaters near the village of Volio, } \mathrm{N} \text { of } \\
\text { San Ramón. It flows } \mathrm{S}, \mathrm{E} \text { and } \mathrm{S} \text { until about } 3 \text { miles } \mathrm{S} \\
\text { of Atenas, where it meets the Río Virilla. From that } \\
\text { point on to its mouth in the Pacific it receives the name } \\
\text { of Río Grande de Tárcoles }\end{array}$ \\
\hline Río Grande & $485 \mathrm{~m}, 9^{\circ} 57^{\prime} \mathrm{N} 84^{\circ} 21^{\prime} \mathrm{W}$ & Village to the SE of Atenas \\
\hline Río Jesús (de San Ramón) & $870 \mathrm{~m}, 10^{\circ} 02^{\prime} \mathrm{N} 84^{\circ} 31^{\prime} \mathrm{W}$ & $\begin{array}{l}\text { Town along the Carretera Interamericana, between San } \\
\text { Ramón and Esparza; formerly called "San José de San } \\
\text { Ramón" }\end{array}$ \\
\hline $\begin{array}{l}\text { Río Saíno (or Quebrada Saíno, } \\
\text { spelled by Endrés 'Sajino’) }\end{array}$ & & $\begin{array}{l}\text { Creek about } 6 \text { miles north of Zarcero, flows into the } \\
\text { Tapezco River }\end{array}$ \\
\hline Salvaje (Alto or Cerro del) & $2000 \mathrm{~m}, 9^{\circ} 51^{\prime} \mathrm{N} 84^{\circ} 10^{\prime} \mathrm{W}$ & $\begin{array}{l}\text { Peak in the Cerros de Escazú, about } 6 \mathrm{~km} \text { to the E of } \\
\text { Palmichal de Acosta }\end{array}$ \\
\hline San Carlos & $150 \mathrm{~m}$ & $\begin{array}{l}\text { Atlantic cantón of Prov. Alajuela; the name technically } \\
\text { refers to the entire cantón, but is frequently used } \\
\text { narrowly for Ciudad Quesada, or very broadly (in the } \\
\text { sense of "Llanura de San Carlos" = San Carlos valley) } \\
\text { to include portions of adjacent cantones }\end{array}$ \\
\hline
\end{tabular}




\begin{tabular}{|c|c|c|}
\hline Locality name on Endrés label & Coordinates & Note \\
\hline San Cristóbal (de Candelaria) & $1710 \mathrm{~m}, 9^{\circ} 47^{\prime} \mathrm{N} 84^{\circ} 01^{\prime} \mathrm{W}$ & Town in the N Cordillera de Talamanca \\
\hline San Francisco de San Ramón & $911 \mathrm{~m}, 10^{\circ} 05^{\prime} \mathrm{N} 84^{\circ} 33^{\prime} \mathrm{W}$ & Town in the Cordillera de Tilarán, W of San Ramón \\
\hline San Gerardo & & $\begin{array}{l}\text { Gold (?) mine in the district of Santiago, SW of San } \\
\text { Ramón }\end{array}$ \\
\hline San Isidro (de Alajuela) & $1360 \mathrm{~m}, 10^{\circ} 05^{\prime} \mathrm{N} 84^{\circ} 12^{\prime} \mathrm{W}$ & Village 5.5 miles NNE of Alajuela \\
\hline San José & $1160 \mathrm{~m}, 9^{\circ} 56^{\prime} \mathrm{N} 84^{\circ} 05^{\prime} \mathrm{W}$ & $\begin{array}{l}\text { City in the Valle Central; capital of Costa Rica and of } \\
\text { Prov. San José }\end{array}$ \\
\hline San Juan de San Ramón & $1140 \mathrm{~m}, 10^{\circ} 07^{\prime} \mathrm{N} 84^{\circ} 28^{\prime} \mathrm{W}$ & N suburb of San Ramón \\
\hline San Lorenzo, Río & $330 \mathrm{~m}, 10^{\circ} 18^{\prime} \mathrm{N} 84^{\circ} 33^{\prime} \mathrm{W}$ & $\begin{array}{l}\text { River draining the N slope of the Cordillera de Tilarán; } \\
\text { an affluent (with the Río Balsa) of the Río Jabillos }\end{array}$ \\
\hline San Mateo & $254 \mathrm{~m}, 9^{\circ} 57^{\prime} \mathrm{N} 84^{\circ} 31^{\prime} \mathrm{W}$ & Village 2.2 miles $\mathrm{N}$ of Orotina \\
\hline San Miguel de Desamparados & $1200 \mathrm{~m}, 9^{\circ} 52^{\prime} \mathrm{N} 84^{\circ} 04^{\prime} \mathrm{W}$ & S suburb of San José \\
\hline $\begin{array}{l}\text { San Pablo [de San Mateo; } \\
\text { de Puriscal; de Turrubares] }\end{array}$ & $373 \mathrm{~m}, 9^{\circ} 54^{\prime} \mathrm{N} 84^{\circ} 27^{\prime} \mathrm{W}$ & $\begin{array}{l}\text { Town in the valley of the Río Grande de Tárcoles; } \\
\text { properly belongs to the Cantón de Turrubares }\end{array}$ \\
\hline San Pedro de Poás (de Alajuela) & $1145 \mathrm{~m}, 10^{\circ} 05^{\prime} \mathrm{N} 84^{\circ} 15^{\prime} \mathrm{W}$ & $\begin{array}{l}\text { Town NW of Alajuela, on the S slope of Volcán Poás; } \\
\text { formerly known as San Pedro de La Calabaza }\end{array}$ \\
\hline San Ramón & $1050 \mathrm{~m}, 10^{\circ} 05^{\prime} \mathrm{N} 84^{\circ} 28^{\prime} \mathrm{W}$ & Major town in the W Valle Central \\
\hline San Roque & $1088 \mathrm{~m} .10^{\circ} 17^{\prime} \mathrm{N} 84^{\circ} 17^{\prime} \mathrm{W}$ & Village to the $\mathrm{N}$ of Grecia \\
\hline Santa Ana & $900 \mathrm{~m}, 9^{\circ} 56^{\prime} \mathrm{N} 84^{\circ} 11^{\prime} \mathrm{W}$ & $\begin{array}{l}\text { Town in the Valle Central, S of Alajuela and W of San } \\
\text { José }\end{array}$ \\
\hline Santa María (de Dota) & $1548 \mathrm{~m}$ & $\begin{array}{l}\text { Town along the Río Pirrís, in the } \mathrm{N} \text { part of the } \\
\text { Cordillera de Talamanca. We remember the name in } \\
\text { Lepanthes dotae Endres ex Luer }\end{array}$ \\
\hline (Fila de) Santa María (de Dota) & & Chain of hills about 2 miles south of S.ta María de Dota \\
\hline Santo Domingo de Vara Blanca & $1500 \mathrm{~m}, 10^{\circ} 13^{\prime} \mathrm{N} 84^{\circ} 08^{\prime} \mathrm{W}$ & Site on the NW slope of Volcán Barva \\
\hline Santiago (de Puriscal) & $1102 \mathrm{~m}, 9^{\circ} 51^{\prime} \mathrm{N} 84^{\circ} 19^{\prime} \mathrm{W}$ & $\begin{array}{l}\text { Main town in the Puriscal region, SW of Ciudad Colón; } \\
\text { nowadays, the town is usually called simply "Puriscal" }\end{array}$ \\
\hline Silencio de San Ramón (El) & $1130 \mathrm{~m}, 10^{\circ} 10^{\prime} \mathrm{N} 84^{\circ} 28^{\prime} \mathrm{W}$ & Site in the Cordillera de Tilarán, N of San Ramón \\
\hline Sitio (El) & & $\begin{array}{l}\text { A farm property of Don Eusebio Ortiz to the NE of } \\
\text { Juan Viñas. A resting place for those who ascended the } \\
\text { Turrialba volcano. In Seebach's description of his } \\
\text { ascent, he writes: "At } 11 \text { a.m. we arrived at a small } \\
\text { plateau on which one can see a pasture with a house } \\
\text { and some huts. This pasture is the 'Sitio de Eusebio } \\
\text { Ortiz' and the last colony or hamlet in the proximity of } \\
\text { the Turrialba." (Liceo de Costa Rica, 1922: 19) }\end{array}$ \\
\hline Tabarcia (spelled often 'Taburcia') & $817 \mathrm{~m}, 9^{\circ} 51^{\prime} \mathrm{N} 84^{\circ} 14^{\prime} \mathrm{W}$ & $\begin{array}{l}\text { Town at the SW base of the Cerros de Escazú. One of } \\
\text { Endrés' discoveries (Endrés 626) was named by him } \\
\text { Lepanthes tabarciae, known today as Lepanthes } \\
\text { inescata Luer }\end{array}$ \\
\hline Tablazo & 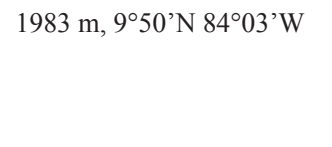 & $\begin{array}{l}\text { Promontory on the S skyline of the Valle Central, } \\
\text { between the Cerros de Escazú and the Cerros de La } \\
\text { Carpintera, on the divide between the Río Virilla and } \\
\text { the Río Grande de Candelaria }\end{array}$ \\
\hline
\end{tabular}




\begin{tabular}{|c|c|c|}
\hline Locality name on Endrés label & Coordinates & Note \\
\hline Tapesco (or Tapezco) de Zarcero & $1860 \mathrm{~m}, 10^{\circ} 13^{\prime} \mathrm{N} 84^{\circ} 23^{\prime} \mathrm{W}$ & $\begin{array}{l}\text { Town in the westernmost Cordillera Central, just NW } \\
\text { of Zarcero along the road to Ciudad Quesada }\end{array}$ \\
\hline Tapesco River & $1600-1700 \mathrm{~m}$ & ca. 6 miles $\mathrm{N}$ of Zarcero \\
\hline Tarrazú (Río) & $1800 \mathrm{~m}, 9^{\circ} 46^{\prime} \mathrm{N} 83^{\circ} 59^{\prime} \mathrm{W}$ & $\begin{array}{l}\text { River to the SE of Cartago, with headwaters near La } \\
\text { Sierra }\end{array}$ \\
\hline Tarrazú (San Marcos de) & $1404 \mathrm{~m} .9^{\circ} 40^{\prime} \mathrm{N} 84^{\circ} 01^{\prime} \mathrm{W}$ & $\begin{array}{l}\text { Village on the Río Pirrís, formerly known as 'Atarrazú, } \\
\text { which is the name used by Endrés }\end{array}$ \\
\hline (El) Tejar & $1380 \mathrm{~m}, 9^{\circ} 51^{\prime} \mathrm{N} 83^{\circ} 57^{\prime} \mathrm{W}$ & SW suburb of Cartago \\
\hline Tobosi & $1400 \mathrm{~m}, 9^{\circ} 50^{\prime} \mathrm{N} 83^{\circ} 59^{\prime} \mathrm{W}$ & $\begin{array}{l}\text { Town along the Río Purires, at the extreme SE corner of } \\
\text { the E Valle Central }\end{array}$ \\
\hline Trinchera (Finca la) & $90 \mathrm{~m}, 10^{\circ} 30^{\prime} \mathrm{N} 84^{\circ} 15^{\prime} \mathrm{W}$ & Farm and hamlet 4 miles N of Pital de San Carlos \\
\hline Tucurrique & $777 \mathrm{~m}, 9^{\circ} 52^{\prime} \mathrm{N} 83^{\circ} 44^{\prime} \mathrm{W}$ & Town along the Río Reventazón, SW of Turrialba \\
\hline Turrialba (spelled 'Turialba') & $650 \mathrm{~m}, 9^{\circ} 54^{\prime} \mathrm{N} 83^{\circ} 42^{\prime} \mathrm{W}$ & $\begin{array}{l}\text { Major town at the SE base of Volcán Turrialba, in the } \\
\text { valley of the Río Reventazón }\end{array}$ \\
\hline Turrialba, Río & $500-600 \mathrm{~m}, 9^{\circ} 54^{\prime} \mathrm{N} 83^{\circ} 39^{\prime} \mathrm{W}$ & $\begin{array}{l}\text { River draining the S slope of Volcán Turrialba; a } \\
\text { tributary of the Río Reventazón }\end{array}$ \\
\hline Ujarrás (spelled 'Ujarráz’) & $1025 \mathrm{~m}, 9^{\circ} 50^{\prime} \mathrm{N} 83^{\circ} 46^{\prime} \mathrm{W}$ & Village in the valley of Orosi \\
\hline Volio, Potrero, Quebrada, Hacienda & $1200 \mathrm{~m}, 10^{\circ} 0^{\prime} \mathrm{N} 84^{\circ} 27^{\prime} \mathrm{W}$ & $\begin{array}{l}\text { Formerly the farm of the prosperous family of don } \\
\text { Julián Volio, today a small village to the N of San } \\
\text { Ramón }\end{array}$ \\
\hline Zapote (spelled 'Sapote') & $1544 \mathrm{~m}, 10^{\circ} 13^{\prime} \mathrm{N} 84^{\circ} 22^{\prime} \mathrm{W}$ & Village on the road from Naranjo to San Carlos \\
\hline Zarcero (spelled 'Sarsero') & $1782 \mathrm{~m}, 10^{\circ} 11^{\prime} \mathrm{N} 84^{\circ} 20^{\prime} \mathrm{W}$ & Village on the road from Naranjo to San Carlos \\
\hline \multicolumn{3}{|c|}{ Panama } \\
\hline Matachín Station & & $\begin{array}{l}\text { Station of the Panama Railroad, close to the confluence } \\
\text { of the Chagres and Obispo Rivers }\end{array}$ \\
\hline Obispo Station & & $\begin{array}{l}\text { Station of the Panama Railroad, just E of Matachin, on } \\
\text { the Obispo River }\end{array}$ \\
\hline San Pablo Station & & $\begin{array}{l}\text { Station of the Panama Railroad, about half a mile south } \\
\text { of the bridge over the Chagres River }\end{array}$ \\
\hline
\end{tabular}


